\title{
PRECOMBUSTION REMOVAL OF HAZARDOUS AIR POLLUTANT PRECURSORS
}

\author{
Contract No.: DE-AC22-95PC95154 \\ Technical Project Report for the Third Quarter \\ April 1, 1996 -- June 30, 1996
}

\section{Prime Contractor:}

Department of Mining and Minerals Engineering

Virginia Polytechnic Institute and State University

Blacksburg, Virginia 24061-0239

\author{
Subcontractors: \\ Clark-Atlanta University \\ Southern Illinois University at Carbondale \\ Electric Power Research Institute \\ Consol Inc.
}

\section{Prepared for:}

Pittsburgh Energy Technology Center

U.S. Department of Energy

P.O. Box 10940

Pittsburgh, Pennsylvania 15236

Contracting Officer's Representative: Richard Read

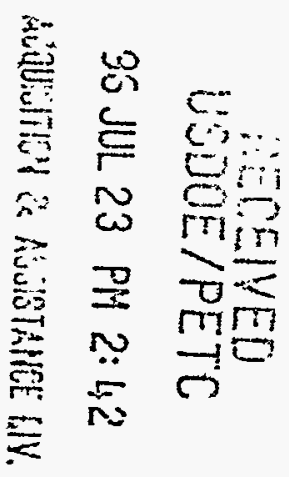

Date Submitted: July 19, 1996

BISTRIBUTION OF THIS DOCUMENT IS UNLIMITED

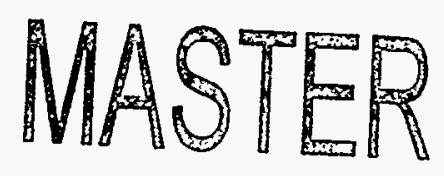




\section{DISCLAIMER}

This report was prepared as an account of work sponsored by an agency of the United States Government. Neither the United States Government nor any agency thereof, nor any of their employees, makes any warranty, express or implied, or assumes any legal liability or responsibility for the accuracy, completeness, or usefulness of any information, apparatus, product, or process disclosed, or represents that its use would not infringe privately owned rights. Reference herein to any specific commercial product, process, or service by trade name, trademark, manufacturer, or otherwise does not necessarily constitute or imply its endorsement, recommendation, or favoring by the United States Government or any agency thereof. The views and opinions of authors expressed herein do not necessarily state or reflect those of the United States Government or any agency thereof. 


\section{DISCLAIMER}

Portions of this document may be illegible in electronic image products. Images are produced from the best available original document. 


\begin{abstract}
This project involves the development of an optimized, bench-scale processing circuit capable of efficiently removing trace elements from run-of-mine coals. The optimized circuit will be developed using characterization data obtained from detailed washability studies and release analyses tests conducted with several eastern U.S. coals. The optimized circuit will incorporate a variety of conventional and advanced coal cleaning processes which are believed to be the most cost-effective and commercially viable. The coal products from the optimized circuit will be further treated with complexing agents specifically designed to extract organometallic trace elements that are difficult to remove by physical cleaning operations. Finally, innovative bioremediation schemes will be investigated as a means of controlling the release of trace elements from the process waste streams. Emphasis has been placed on the development of a processing circuit which (i) maximizes the rejection of trace elements, (ii) minimizes the production of coal fines which are costly to process and less marketable, and (iii) minimizes the downstream impacts of the process waste streams on the environment.
\end{abstract}

During the past quarter, the project work plan and all associated technical/management reports were successfully approved (Subtask 1.1 - Work Plan Development). Activities associated with the selection and acquisition of all three base coal samples have also been completed (Subtask 2.1 - Coal Selection and Subtask 2.2 - Coal Procurement. Test work is now actively moving forward on several different fronts. Characterization work is continuing to move ahead at an accelerated pace in both Subtask 3.2 - Washability Analysis and Subtask 3.3 Flotation Release Analyses. In addition, mineralogical analyses are underway as part of the characterization work. These tests are being conducted to establish statistical correlations between mineral content and trace element occurrence. In Task 4 - Bench-Scale Testing, the experimental program is now well underway to assess the trace element cleanability of the Pittsburgh No. 8 coal. Effort has also been initiated under Task 4 - Toxics Fate Studies to identify viable methods for controlling the release of trace metals from refuse samples for the Pittsburgh No. 8 seam. Since several of the project subtasks are still behind schedule, additional manpower continues to be allocated in an effort to bring all project activities back on time.

\title{
BACKGROUND
}

Coal preparation is widely regarded a cost-effective method for reducing the amounts of potentially hazardous air pollutant precursors (HAPPs) which occur as trace elements in run-ofmine coals. Unfortunately, many existing coal preparation plants are inefficient in removing trace elements because of poor circuit design and inadequate liberation of coal and mineral matter. These shortcomings are often difficult to correct in the absence of characterization data regarding the mineralogical association and washability of trace elements in run-of-mine coals.

In the present work, detailed trace element characterization studies will be conducted using samples from three different coal producing regions in the U.S. Using the characterization data, size classes, density fractions, etc., will be identified that are capable of meeting the desired trace element cleanup levels using low-cost conventional technologies such as heavy media bath, cyclones, spirals, 
etc. Composite (middling) particles that do not meet these criteria will be pulverized to improve liberation and subjected to a second series of characterization studies. This information will be used to determine whether additional clean coal can be recovered from the middlings fractions.

Based on input provided by the industrial participants, one of the three base coal samples will be selected and subjected to a series of bench-scale tests using a wide variety of advanced physical separation processes. Processes evaluated in the bench-scale study will include column flotation cells and enhanced centrifugal gravity separators. These processes are believed to have the highest overall probability of gaining industrial acceptance. Data obtained from the bench-scale tests will be used to design optimum circuit configurations for the removal of trace elements. The various types of fine coal processing technologies may be combined in series to achieve high rejections of trace elements without ultrafine grinding.

To further enhance the removal of trace elements, the clean coal products from the benchscale tests will be treated using complexing agents. These reagents are designed to combine with specific elements and increase their effective solubility range. This "polishing" step will allow for the incremental removal of organically bound or poorly liberated trace elements that cannot be rejected by physical cleaning. In addition, some of the waste streams from the bench-scale tests will be subjected to a variety of laboratory tests to formulate strategies for controlling the release of trace elements discarded into refuse impoundments. Finally, the data obtained from the characterization studies and bench-scale tests will be used to develop a conceptual design for a proof-of-concept (POC) plant which maximizes coal recovery and trace element rejection.

\section{PROJECT OBJECTIVES}

The primary objective of this project is to develop and evaluate an advanced coal cleaning circuit that is capable of removing hazardous air pollutant precursors from run-of-mine coals in an efficient and cost-effective manner. Specific objectives of Phase I activities are (i) to determine the types and relative amounts of trace elements present in several eastern U.S. coals, (ii) to devise and test bench-scale circuits capable of maximizing the recovery of coal and the rejection of trace elements, (iii) to develop reliable performance data, operating guidelines and scale-up criteria for the proposed circuits, and (iv) to formulate strategies which minimize the downstream impact of trace elements on the effluent streams from the refuse impoundment.

\section{PROJECT TASKS}

\section{Task 1 - Project Planning}

\section{Subtask 1.1 - Work Plan Development}

All documentation related to work plan development, NEPA review and associated project planning have been submitted to the DOE COR and successfully approved. This subtask is now considered to be complete. 
All project reports required during the past quarter have been submitted in a timely fashion to DOE. These include all status, management and technical reports. No delays are currently anticipated in meeting future reporting requirements. A commercial software package (Microsoft Project 4.1) is now being used to track project activities and to coordinate efforts to bring the proposed work effort back on schedule.

\section{Task 2 - Sample Acquisition}

\section{Subtask 2.1 - Coal Selection}

Three different coal samples from major bituminous coal producing regions in the Northern Appalachia, Central Appalachia and the Illinois coal basins have been selected for the proposed test work. Table 1 provides a summary of the coal seams that have been chosen. It was originally planned to utilize a sample of Pocahontas No. 3 coal to represent the Central Appalachia region. However, the Pocahontas No. 3 seam is a high-quality metallurgical coal and contains relatively few middlings particles. As such, this coal was considered to be less attractive for the proposed "regrind" treatment strategy to produce improved fuels for the utility market. Therefore, after extensive discussions with several coal companies, a sample of Coalburg seam coal was identified as a better candidate for use in the present work. According to our preliminary evaluation; this low-sulfur coal contains a relatively high proportion of coarse middling particles that liberate well when subjected to pulverization. The selection of the Coalburg sample permits a wide range of coal seams to be evaluated, i.e., Pittsburgh No. 8 (low middlings), Illinois No. 6 (moderate middlings) and Coalburg (high middlings). The Coalburg sample was acquired from the Pittston Coal Group. This subtask is now considered to be complete.

Table 1 - Coal samples selected for characterization and testing.

\begin{tabular}{ccccc}
\hline Sample & Coal Seam & Coal Region & Supplier & Acquisition \\
\hline 1 & Pittsburgh No. 8 & Northern Appalachia & Consol Inc. & $4,500 \mathrm{~kg}$ \\
2 & Illinois No. 6 & Illinois Basin & EPRI & $900 \mathrm{~kg}$ \\
3 & Coalburg & Central Appalachia & Pittston & $900 \mathrm{~kg}$ \\
\hline
\end{tabular}




\section{Subtask 2.2 - Coal Procurement}

As shown in Table 1, three candidate coal samples were acquired from Consol, EPRI (via Illinois Power) and Pittston. Approximately $900 \mathrm{~kg}$ (1 ton) of run-of-mine sample were acquired for each of the Illinois No. 6 and Coalburg seams. This amount of sample was deemed to be appropriate to complete the proposed float-sink washability studies and flotation release analysis tests (Task 3 - Characterization). A larger sample of 4,500 kg (5 tons) of Pittsburgh No. 8 coal was procured for use in the characterization test work (Task 3 - Characterization) and bench-scale evaluation (Task 4 - Bench-Scale Testing). This subtask is now considered to be complete.

\section{Subtask 2.3 - Preparation and Storage}

All of the candidate coal samples have been carefully prepared and stored at the coal preparation test facility at Virginia Tech. In accordance with the project work plan, all samples have been air-dried and stored in sealed 55 gallon drums. All storage containers have been lined with plastic inserts to prevent contamination. The procedures used during the sample preparation have been outlined in the last technical progress report.

\section{Task 3-Characterization}

\section{Subtask 3.1 - Preliminary Analyses}

Preliminary analyses (proximate and ultimate) of the various base coal samples are now underway at commercial testing laboratories. The results of these analyses will be reported after the data has been tabulated, mass balanced and reviewed. These activities should be easily completed during the next month.

\section{Subtask 3.2 - Washability Analyses}

Float-sink tests for the various base coal samples were continued during the past quarter. This effort has resulted in the generation of a large number of individual samples that must be subjected to laboratory analysis for the determination of ash, sulfur and trace element content. Unfortunately, all washability analyses and all analytical determinations must be completed for each size fraction before a mass balance can be conducted for each coal. Delays associated with the completion of the washability tests and trace element analyses has not permitted a complete mass balance to be achieved at this time for any of the three coal samples. Thus, the complete set of float-sink data cannot be reported until all values are tabulated, mass balanced and evaluated. Preliminary washability data for the Pittsburgh No. 8 and Coalburg seam coals are provided in Appendix I. Current plans call for the completion of all washabilty analyses and associated mass balance calculations by the end of the next quarter. 
Flotation release analysis tests have now been initiated for the fine size fractions (i.e., $28 \times 100$ mesh, 100x270 mesh and 270 mesh $\times 0$ ) of the various base coal samples. Laboratory analyses of the samples are presently underway. These results should be available at the end of the next technical reporting period.

\section{Subtask 3.4 - SEM/Image Analyses}

Characterization work was initiated during the past quarter to establish correlations between trace element content and the mineralogical composition of a $65 \times 100$ mesh sample of Pittsburgh No. 8 coal. The narrowly-sized sample was subjected to float-sink testing over a wide range of specific gravities. To minimize problems associated with sample contamination, a Magstream separator was used to prepare the high density fractions. This device generates an artificial specific gravity by subjecting a ferromagnetic fluid to a high intensity magnetic field.

During the past quarter, mineralogical analyses was completed for the float $1.3,1.4 \times 1.5,1.7$ $x 1.8$ and $1.8 \times 2.0$ specific gravity classes using scanning electron spectroscopy (SEM) coupled with image analysis (IA). Table 2 shows the breakdown of mineralogical components for these specific gravity classes. As expected, the total mineral content increased from $1.36 \%$ to $50.4 \%$ as the specific gravity increased from float $1.3 \mathrm{SG}$ to $1.8 \times 2.0 \mathrm{SG}$. Eight different primary mineral groups were identified during the analyses, i.e., clays, carbonates, oxides, phosphates, salts, silicates, sulfates and sulfides. The amounts of specific minerals identified in each group are provided in Table 3 . The analyses show that the dominant mineral groups were clays, oxides and sulfides. This trend is clearly observed in the three dimensional distribution plot provided in Figure 1. Statistical evaluations of the data will be conducted during the next reporting period after completing the quantitative SEM/IA evaluations and associated trace element analyses.

\section{Task 4-Bench-Scale Testing}

\section{Subtask 4.1 - Heavy Media}

In accordance with the project work plan, a bench-scale test circuit has been assembled for the testing of the Pittsburgh No. 8 seam coal. Shakedown tests have already been completed for the circuit and testing is presently underway. Figures $2-5$ show the material handling requirements and sampling procedures that are being utilized to carefully track the amounts of solids and liquids that pass through the circuit. Figure 2 shows the procedures used to initially size the feed coal. This procedure resulted in the generation of a variety of samples for use in subsequent processing operations and for detailed laboratory analysis (see Figure 3). Likewise, Figures 4 and 5 show the handling requirements and sampling procedures for the 2 inch $\times 10 \mathrm{~mm}$ and the $10 \mathrm{~mm} \times 28$ mesh heavy media test runs. The 2 inch $\times 10 \mathrm{~mm}$ tests were conducted using a heavy media batch constructed from a modified sand screw. The test work for the $10 \mathrm{~mm} \times 28$ mesh runs have not yet been completed. These tests will be conducted using a deep Wemco heavy media cone. As shown by the illustrations, extreme care has been used in the development of the bench-scale sampling and 
Table 2 - Mineralogical breakdown for the Pittsburgh No.8 coal.

\begin{tabular}{|l|c|c|c|c|}
\cline { 2 - 5 } \multicolumn{1}{c|}{} & \multicolumn{4}{c|}{ Percentage of Total Sample } \\
\hline Matter Type & Flt 1.3 & $1.4 \times 1.5$ & $1.7 \times 1.8$ & $1.8 \times 2.0$ \\
\hline Organic & 98.644 & 84.717 & 65.306 & 49.617 \\
Mineral & 1.356 & 15.283 & 34.694 & 50.383 \\
\hline Total & 100.000 & 100.000 & 100.000 & 100.000 \\
\hline
\end{tabular}

\begin{tabular}{|l|c|c|c|c|}
\cline { 2 - 5 } \multicolumn{1}{c|}{} & \multicolumn{4}{c|}{ Precentage of Total Minerals } \\
\hline Mineral Group & Flt 1.3 & $1.4 \times 1.5$ & $1.7 \times 1.8$ & $1.8 \times 2.0$ \\
\hline Clay & 0.887 & 9.332 & 15.896 & 19.732 \\
Carbonate & 0.058 & 0.285 & 1.895 & 5.416 \\
Oxide & 0.276 & 3.034 & 7.580 & 11.543 \\
Phosphate & 0.027 & 0.073 & 0.118 & 0.500 \\
Salt & 0.000 & 0.006 & 0.000 & 0.000 \\
Silicate & 0.000 & 0.003 & 0.065 & 0.147 \\
Sulfate & 0.000 & 0.000 & 0.000 & 0.015 \\
Sulfide & 0.108 & 2.550 & 9.140 & 13.030 \\
\hline Total & 1.356 & 15.283 & 34.694 & 50.383 \\
\hline
\end{tabular}


Table 3 - Detailed mineralogical breakdown for the Pittsburgh No. 8 coal.

\begin{tabular}{|c|c|c|c|c|c|c|c|c|}
\hline \multirow{2}{*}{$\begin{array}{l}\text { Mineral } \\
\text { Matter }\end{array}$} & \multicolumn{4}{|c|}{ Percentage of Total Sample } & \multicolumn{4}{|c|}{ Precentage of Total Minerals } \\
\hline & Flt 1.3 & $1.4 \times 1.5$ & $1.7 \times 1.8$ & $1.8 \times 2.0$ & Fit 1.3 & $1.4 \times 1.5$ & $1.7 \times 1.8$ & $1.8 \times 2.0$ \\
\hline CLAY & 0.887 & 9.332 & 15.896 & 19.732 & 65.413 & 61.061 & 45.818 & 39.164 \\
\hline Kaolinite & 0.601 & 5.362 & 3.910 & 2.911 & 44.322 & 35.085 & 11.270 & 5.778 \\
\hline K-clay & 0.239 & 3.516 & 10.256 & 13.251 & 17.625 & 23.006 & 29.561 & 26.301 \\
\hline Apatite/K-Clay & 0.000 & 0.048 & 0.732 & 2.548 & 0.000 & 0.314 & 2.110 & 5.057 \\
\hline Na-Clay & 0.000 & 0.201 & 0.769 & 0.441 & 0.000 & 1.315 & 2.217 & 0.875 \\
\hline Misc. Clay & 0.047 & 0.205 & 0.229 & 0.581 & 3.466 & 1.341 & 0.660 & 1.153 \\
\hline CARBONATE & 0.058 & 0.285 & 1.895 & 5.416 & 4.277 & 1.865 & 5.462 & 10.750 \\
\hline Ankerite & 0.000 & 0.000 & 0.036 & 0.000 & 0.000 & 0.000 & 0.104 & 0.000 \\
\hline Calcite & 0.057 & 0.271 & 1.436 & 3.791 & 4.204 & 1.773 & 4.139 & 7.524 \\
\hline Dolomite & 0.001 & 0.014 & 0.423 & 1.625 & 0.074 & 0.092 & 1.219 & 3.225 \\
\hline Misc. Carbor & 0.000 & 0.000 & 0.000 & 0.000 & 0.000 & 0.000 & 0.000 & 0.000 \\
\hline OXIDE & 0.276 & 3.034 & 7.580 & 11.543 & 20.354 & 19.852 & 21.848 & 22.911 \\
\hline Quartz & 0.272 & 2.932 & 7.252 & 11.076 & 20.059 & 19.185 & 20.903 & 21.984 \\
\hline Rutile & 0.004 & 0.102 & 0.263 & 0.467 & 0.295 & 0.667 & 0.758 & 0.927 \\
\hline Fe-Oxide & 0.000 & 0.000 & 0.065 & 0.000 & 0.000 & 0.000 & 0.187 & 0.000 \\
\hline Misc. Oxide & 0.000 & 0.000 & 0.000 & 0.000 & 0.000 & 0.000 & 0.000 & 0.000 \\
\hline PHOSPHATE & 0.027 & 0.073 & 0.118 & 0.500 & 1.991 & 0.478 & 0.340 & 0.992 \\
\hline Apatite & 0.027 & 0.073 & 0.118 & 0.500 & 1.991 & 0.478 & 0.340 & 0.992 \\
\hline Misc. Phosphat & 0.000 & 0.000 & 0.000 & 0.000 & 0.000 & 0.000 & 0.000 & 0.000 \\
\hline SALT & 0.000 & 0.006 & 0.000 & 0.000 & 0.000 & 0.039 & 0.000 & 0.000 \\
\hline Gypsum & 0.000 & 0.006 & 0.000 & 0.000 & 0.000 & 0.039 & 0.000 & 0.000 \\
\hline Misc. Salt & 0.000 & 0.000 & 0.000 & 0.000 & 0.000 & 0.000 & 0.000 & 0.000 \\
\hline SILICATE & 0.000 & 0.003 & 0.065 & 0.147 & 0.000 & 0.020 & 0.187 & 0.292 \\
\hline Zircon & 0.000 & 0.000 & 0.000 & 0.015 & 0.000 & 0.000 & 0.000 & 0.030 \\
\hline Misc. Silicate & 0.000 & 0.003 & 0.065 & 0.132 & 0.000 & 0.020 & 0.187 & 0.262 \\
\hline SULFATE & 0.000 & 0.000 & 0.000 & 0.015 & 0.000 & 0.000 & 0.000 & 0.030 \\
\hline Barite & 0.000 & 0.000 & 0.000 & 0.015 & 0.000 & 0.000 & 0.000 & 0.030 \\
\hline Misc. Su & 0.000 & 0.000 & 0.000 & 0.000 & 0.000 & 0.000 & 0.000 & 0.000 \\
\hline SULFIDE & 0.108 & 2.550 & 9.140 & 13.030 & 7.965 & 16.685 & 26.345 & 25.862 \\
\hline Pyrite & 0.108 & 2.550 & 9.140 & 13.017 & 7.965 & 16.685 & 26.345 & 25.836 \\
\hline Sphalerite & 0.000 & 0.000 & 0.000 & 0.013 & 0.000 & 0.000 & 0.000 & 0.026 \\
\hline Misc. Sulfide & 0.000 & 0.000 & 0.000 & 0.000 & 0.000 & 0.000 & 0.000 & 0.000 \\
\hline DTAL & 1.356 & 15.283 & 34.694 & 50.383 & 100.000 & 100.000 & 100.000 & 100.000 \\
\hline
\end{tabular}




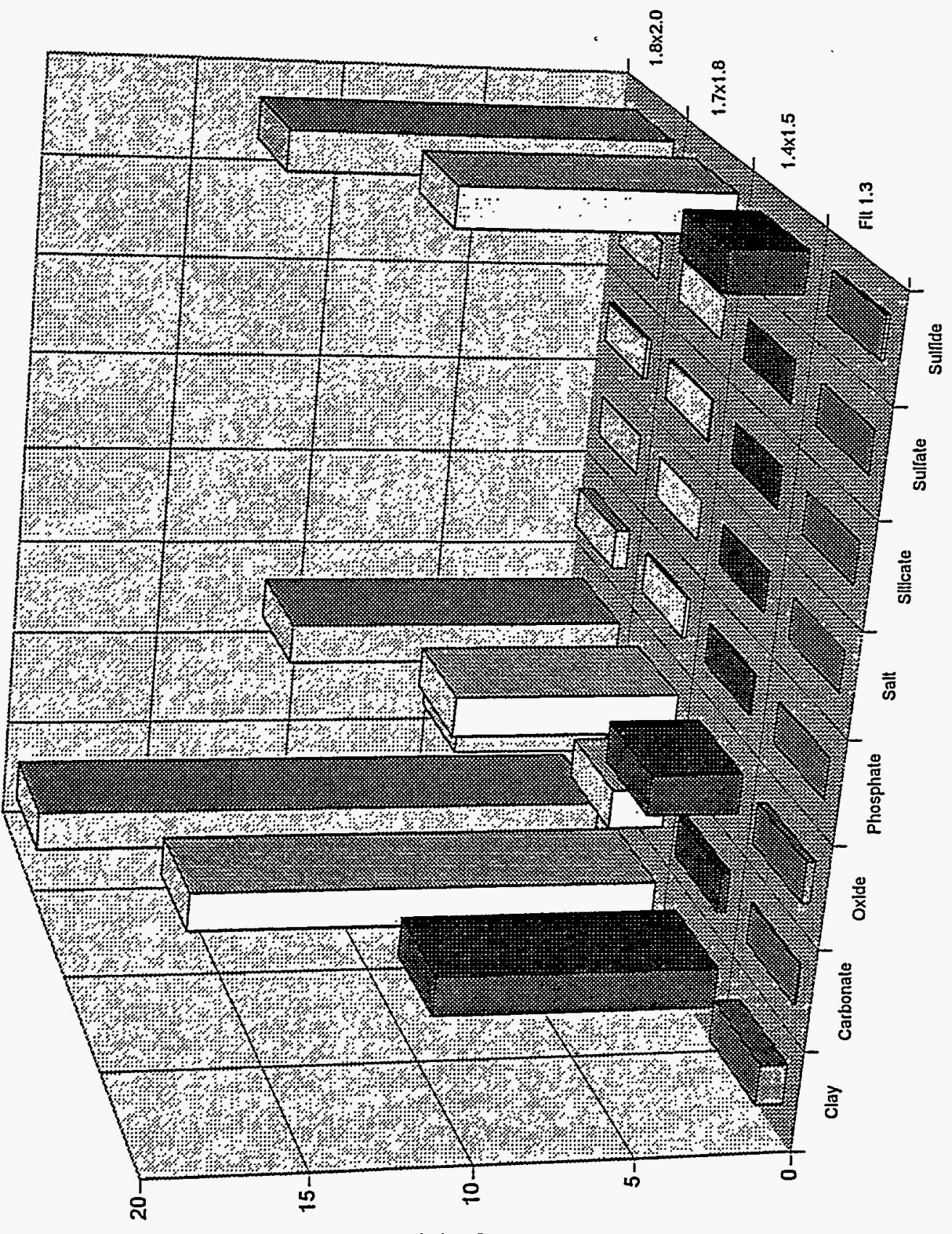

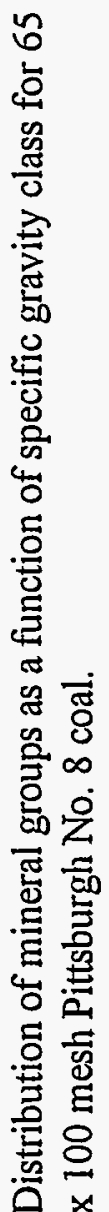

(\%) $746 !$ 


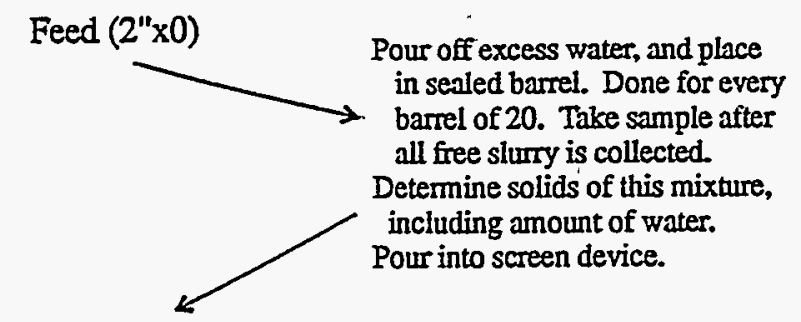

Take three gallon bucket of sample, haif at the beginning of the pour, and the other half towards the end of the pour. Done for each of 20 barrels.

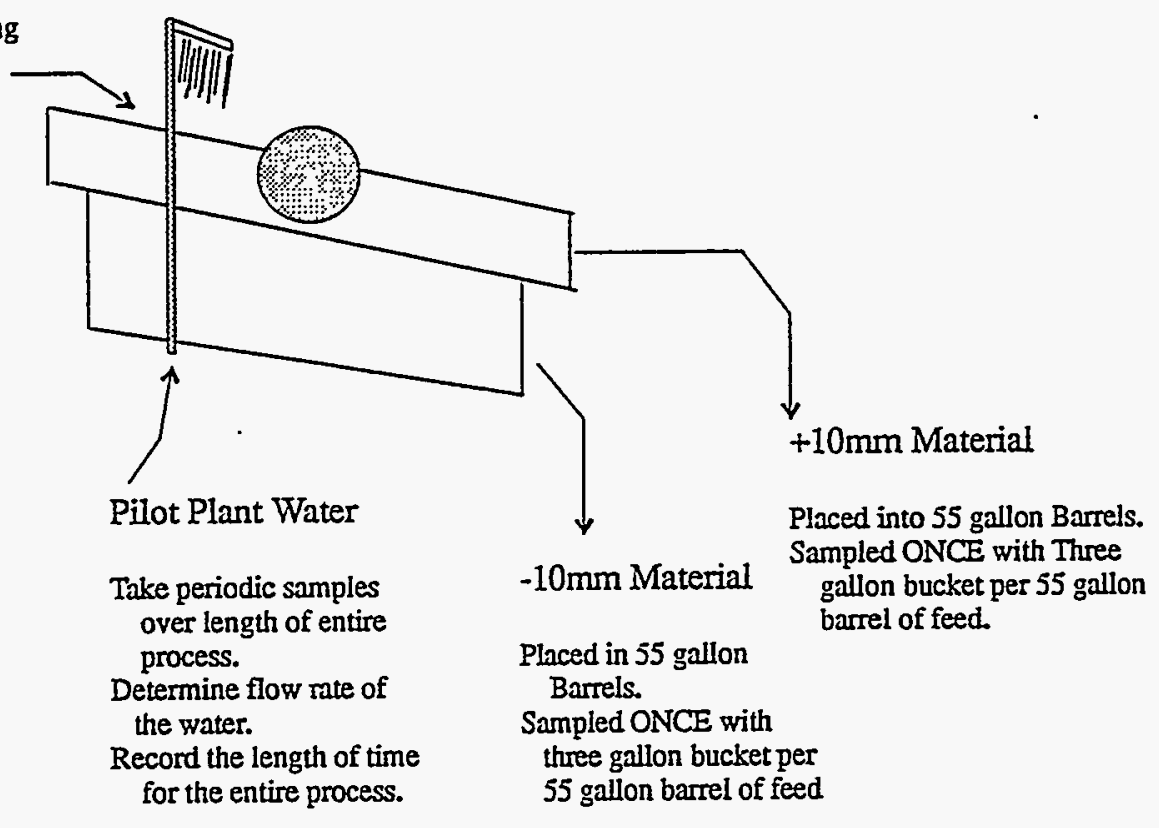

\section{For Each Material Stream:}

Seal all barrels with plastic.

Weigh all barrels, determine amount of coal on an air dried basis, usuing representative samples collected during the screening process.

The above representative samples used to determine moisture content will be used for prox analysis and trace element analysis.

\section{For Representative Samples:}

Rinse Water: Collected to determine flowrate, and trace element concentration. Placed in one container and sampled at the end of the screening.

Coal: Once air dried, crushed and riffled until ausable size sample is obtained.

Figure 2. Overview of the test procedure for the $10 \mathrm{~mm}$ bench-scale screening operation. 


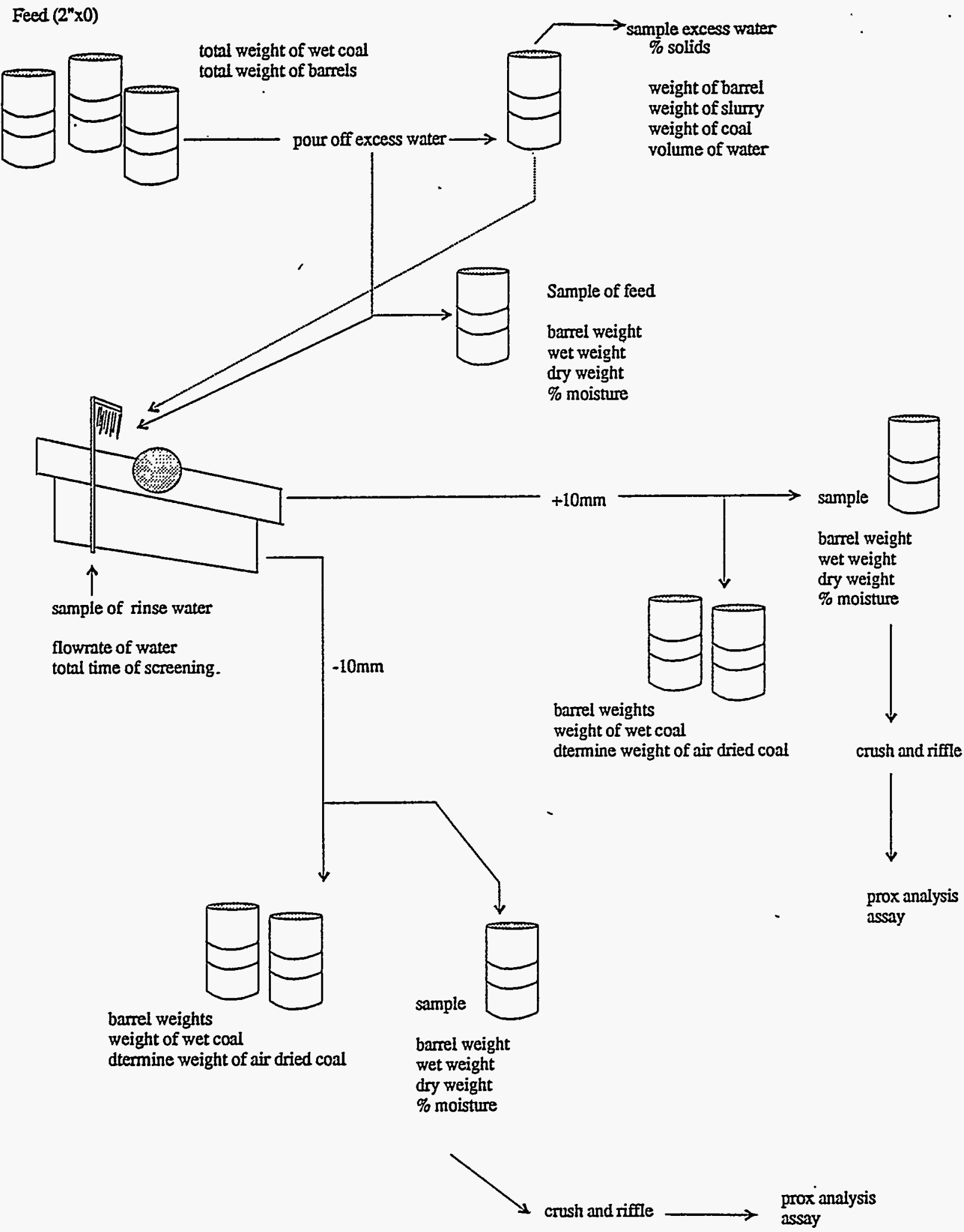

Figure 3. Overview of the sampling procedure for the $10 \mathrm{~mm}$ bench-scale screening operation. 


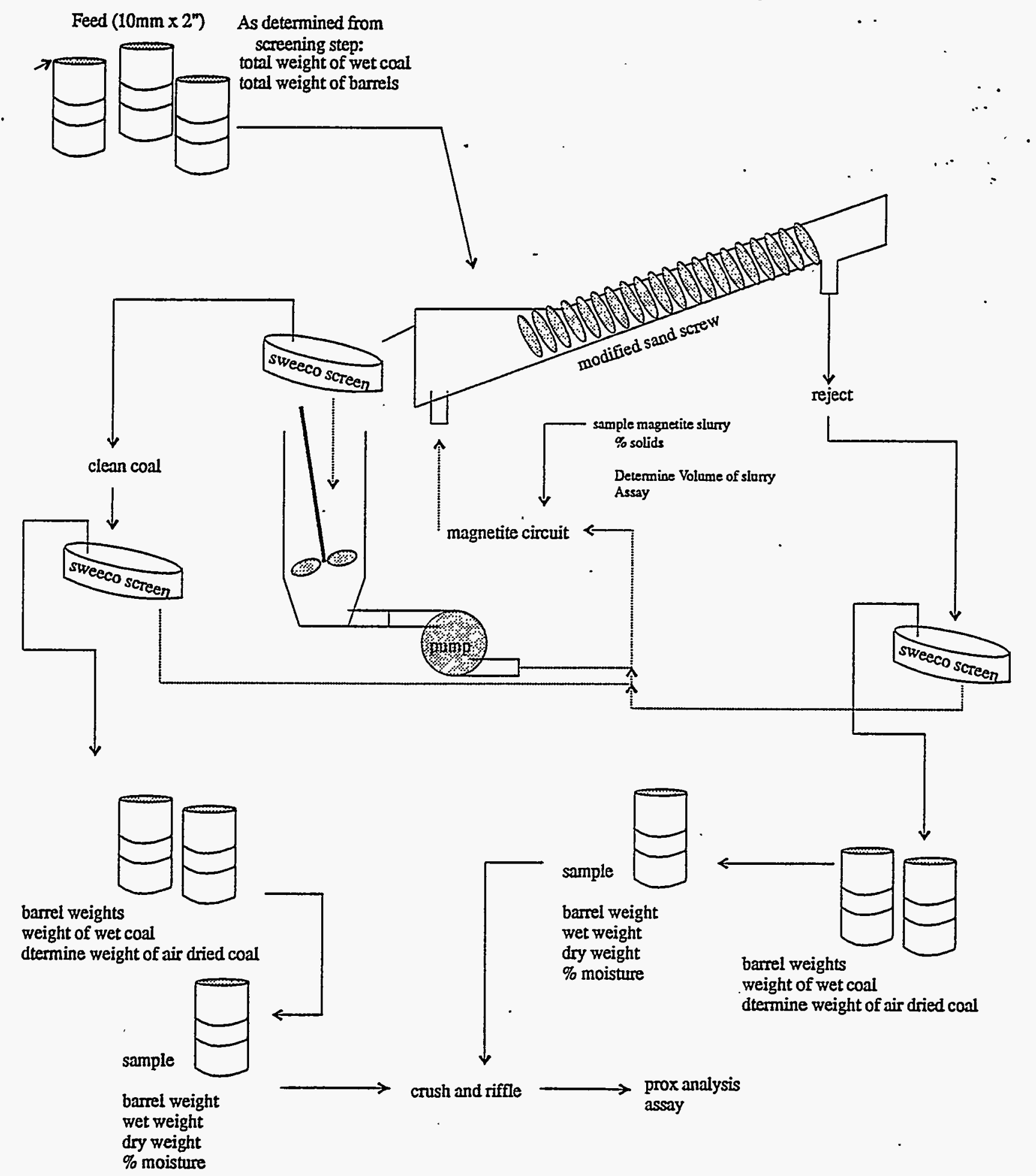

Figure 4. Overview of the test and sampling procedures for the 2 inch $\times 10 \mathrm{~mm}$ dense media separation. 


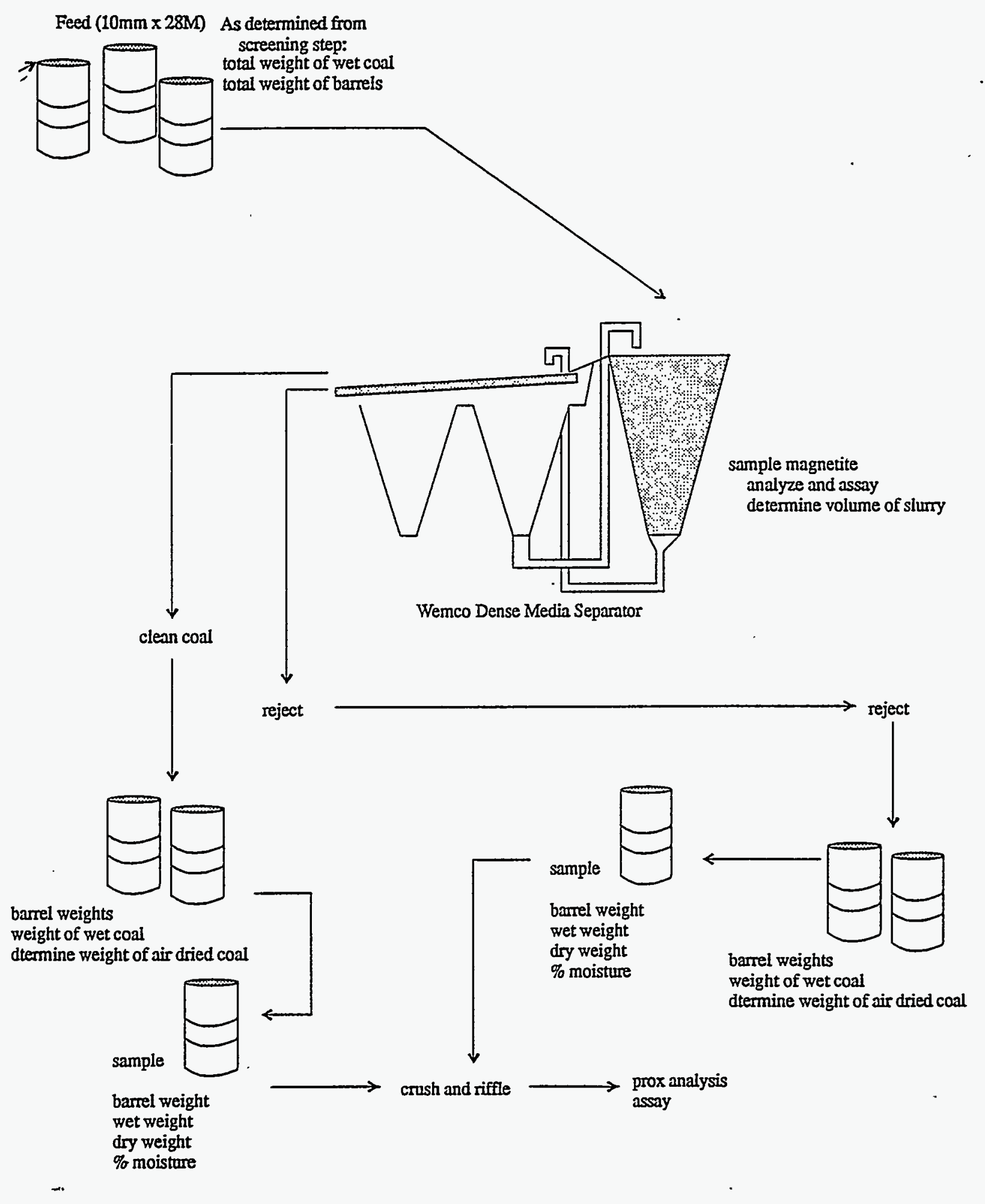

Figure 5. Overview of the test and sampling procedures for the $10 \mathrm{~mm} \times 28 \mathrm{mesh}$ dense media separation. 
testing procedures. This was necessary to ensure that complete material balances can be maintained around each unit operation and throughout the entire test circuit. The material balance is particularly important for tracking track trace elements that may become soluble.

\section{Task 6 - Toxic Fate Studies}

Subtask 6.1 - Analysis of Pond Toxics

A sample of Pittsburgh No. 8 coal refuse has been prepared using the heavy media circuit and shipped to Clark Atlanta University for use in their test program involving bioremediation via microbial mats. Because of delays associated with sample receipt, this task is running behind schedule and no data is currently available. This task will be accelerated and should be brought back on schedule during the next several months. There should be no problem in finishing the task before the project completion deadline.

\section{Task 9 - Sample Analyses}

Subtask 9.1 - Coal Analyses

This task is presently running behind schedule because of the large amounts of samples recently generated by the characterization work (Task 3 - Characterization). Work is presently underway to clear the backlog of samples.

\section{Subtask 9.2 - Trace Element Analyses}

Problems associated with contractual agreements for trace element analyses have now been resolved. No additional delays are anticipated for the completion of all elemental determinations. An expansion of the mass balance software to include trace elements is also presently underway and should be completed during the next reporting period.

\section{SUMMARY, STATUS AND PLANNED WORK}

The project work plan and all associated technical/management reports were successfully approved by the COR during the past quarter (Subtask 1.1 - Work Plan Development). Activities associated with the acquisition of the base coal samples (Subtask 2.1 - Coal Selection and Subtask 2.2 - Procurement Test) has also been completed. Characterization work is continuing to move ahead at an accelerated pace in Subtask 3.1 - Preliminary Analyses, Subtask 3.2 - Washability Analysis and Subtask 3.3 - Flotation Release Analyses. , Subtask 4.1 - Heavy Media, Task 6 - Toxics Fate Studies and Task 9 - Sample Analyses. Although several of the project subtasks are behind schedule as a result of unexpected delays, additional manpower has been allocated to bring project activities back on schedule. 
$=$ APPENDIX I $=$

Washability Data

Coalburg Seam

Pittsburgh No. 8 Seam 


\section{Coalburg Seam}

\begin{tabular}{|c|c|c|c|c|}
\hline \multicolumn{2}{|c|}{ Size Class } & Elementary & $\begin{array}{c}\text { Retained } \\
(\%)\end{array}$ & $\begin{array}{c}\text { Passing } \\
(\%)\end{array}$ \\
\hline Passing & Retained & & $(\%)$ \\
\hline & 2 Inch & 19.73 & 19.73 & 100.00 \\
1/4 Inch & $1 / 4$ Inch & 52.82 & 72.55 & 80.27 \\
28 Mesh & 28 Mesh & 20.42 & 92.97 & 27.45 \\
100 Mesh & 100 Mesh & 3.21 & 96.18 & 7.03 \\
& & 3.82 & 100.00 & 3.82 \\
& & & & \\
& & & & \\
& & & & \\
& & & & \\
& & & & \\
\end{tabular}




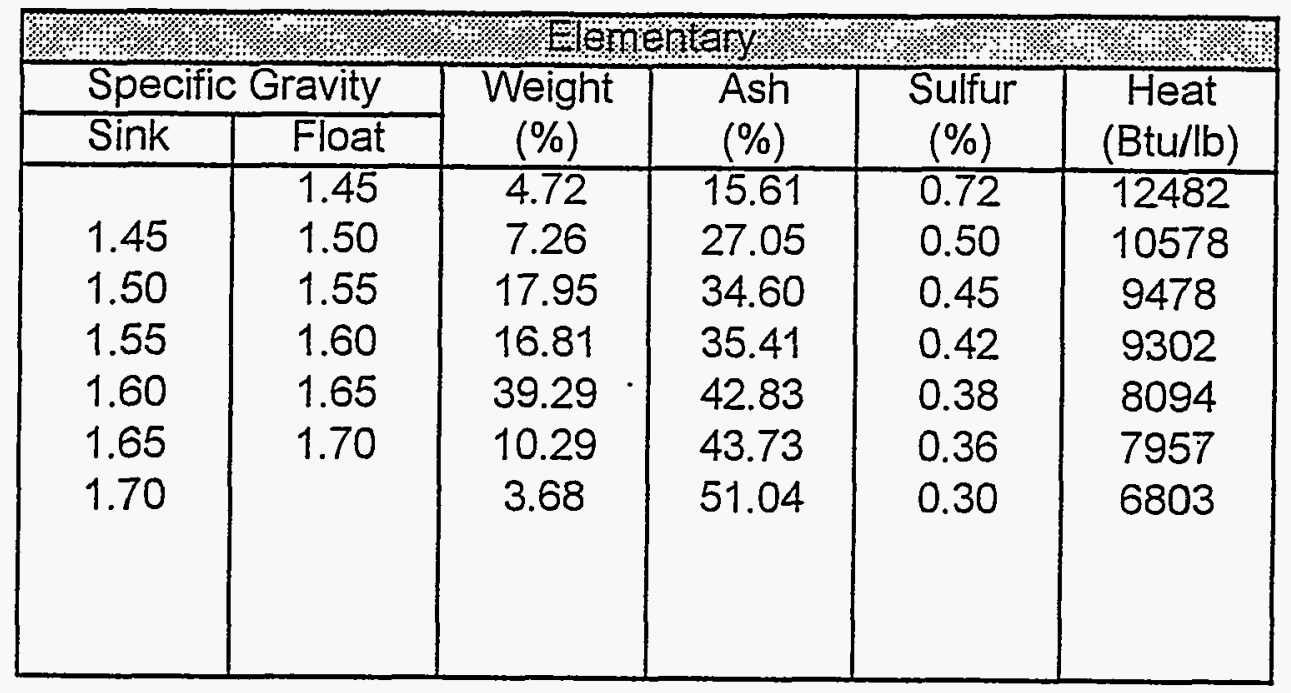

\begin{tabular}{|c|c|c|c|c|c|}
\hline \multicolumn{6}{|c|}{ (1.7. } \\
\hline \multicolumn{2}{|c|}{ Specific Gravity } & \multirow{2}{*}{$\begin{array}{l}\text { Weight } \\
(\%)\end{array}$} & \multirow{2}{*}{$\begin{array}{l}\text { Ash } \\
(\%)\end{array}$} & \multirow{2}{*}{$\begin{array}{l}\text { Sulfur } \\
(\%)\end{array}$} & \multirow{2}{*}{$\begin{array}{c}\text { Heat } \\
\text { (Btu/lb) }\end{array}$} \\
\hline Sink & Float & & & & \\
\hline & 1.45 & 4.72 & 15.61 & 0.72 & 12482 \\
\hline 1.45 & 1.50 & 11.98 & 22.54 & 0.59 & 11328 \\
\hline 1.50 & 1.55 & 29.93 & 29.77 & 0.50 & 10219 \\
\hline 1.55 & 1.60 & 46.74 & 31.80 & 0.47 & 9889 \\
\hline 1.60 & 1.65 & 86.03 & 36.84 & 0.43 & 9069 \\
\hline 1.65 & 1.70 & 96.32 & 37.57 & 0.42 & 8950 \\
\hline 1.70 & & 100.00 & 38.07 & 0.42 & 8871 \\
\hline & & & & & \\
\hline & & & & & \\
\hline
\end{tabular}

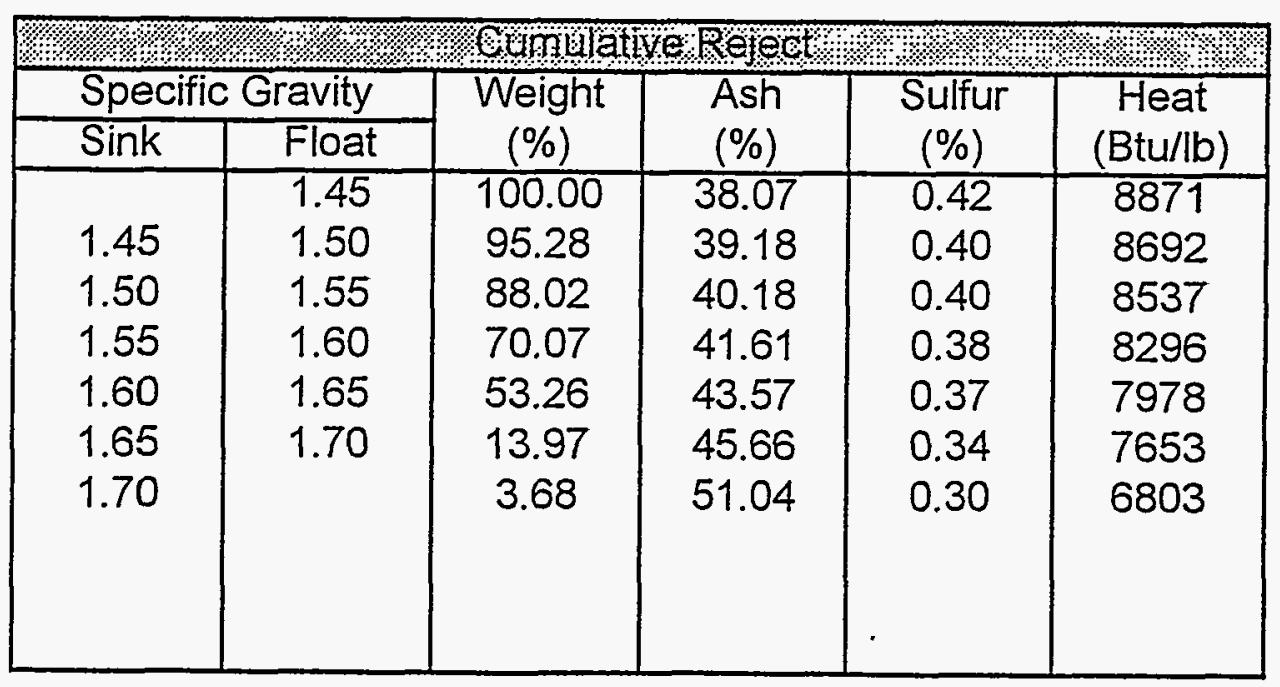




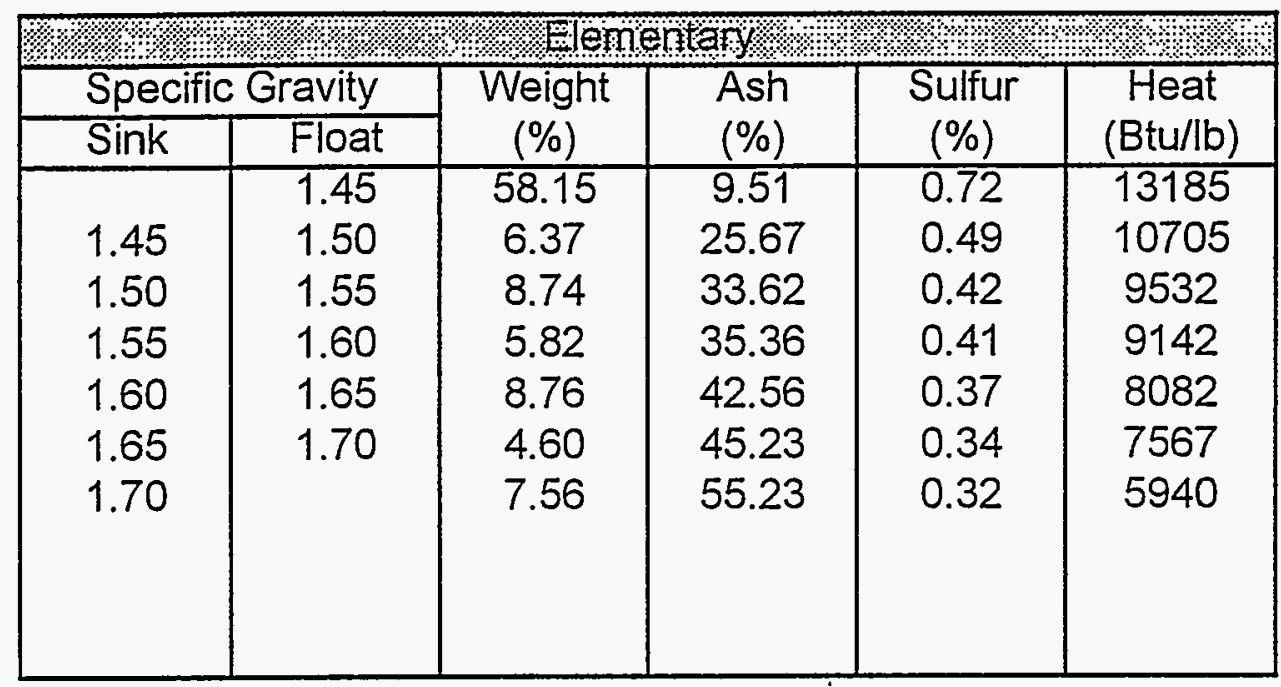

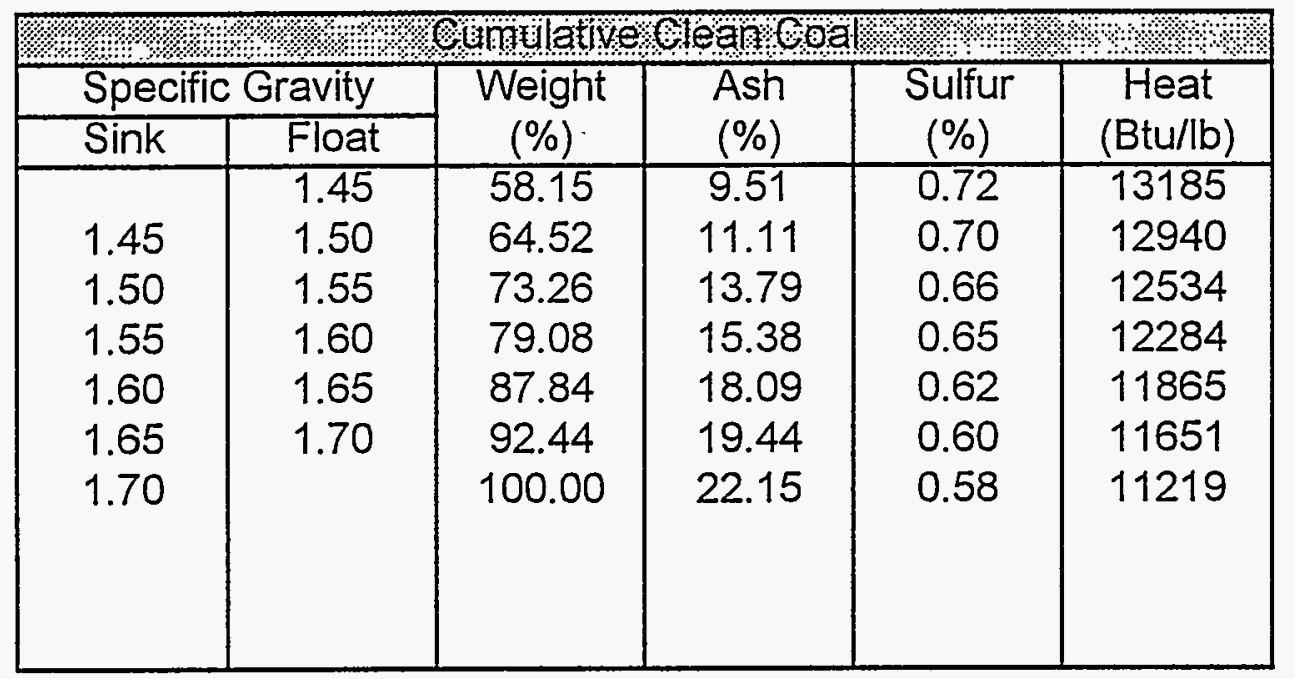

\begin{tabular}{|c|c|c|c|c|c|}
\hline \multirow{2}{*}{\multicolumn{2}{|c|}{ Specific Gravity }} & \multicolumn{2}{|c|}{ Crimulative $R e j e c t$} & \multicolumn{2}{|c|}{ \% } \\
\hline & & \multirow{2}{*}{$\begin{array}{c}\text { Weight } \\
(\%)\end{array}$} & \multirow{2}{*}{$\begin{array}{l}\text { Ash } \\
(\%)\end{array}$} & \multirow{2}{*}{$\begin{array}{c}\text { Sulfur } \\
(\%)\end{array}$} & \multirow{2}{*}{$\begin{array}{c}\text { Heat } \\
\text { (Btu/lb) }\end{array}$} \\
\hline Sink & Float & & & & \\
\hline & 1.45 & 100.00 & 22.15 & 0.58 & 11219 \\
\hline 1.45 & 1.50 & 41.85 & 39.70 & 0.39 & 8488 \\
\hline 1.50 & 1.55 & 35.48 & 42.22 & 0.37 & 8090 \\
\hline 1.55 & 1.60 & 26.74 & 45.03 & 0.36 & 7619 \\
\hline 1.60 & 1.65 & 20.92 & 47.73 & 0.35 & 7195 \\
\hline 1.65 & 1.70 & 12.16 & 51.45 & 0.33 & 6555 \\
\hline 1.70 & & 7.56 & 55.23 & 0.32 & 5940 \\
\hline & & & & & \\
\hline & & & & & \\
\hline
\end{tabular}


Coalburg Seam

2 Inch $\times 100$ Mesh $-96.18 \%$ Wt.

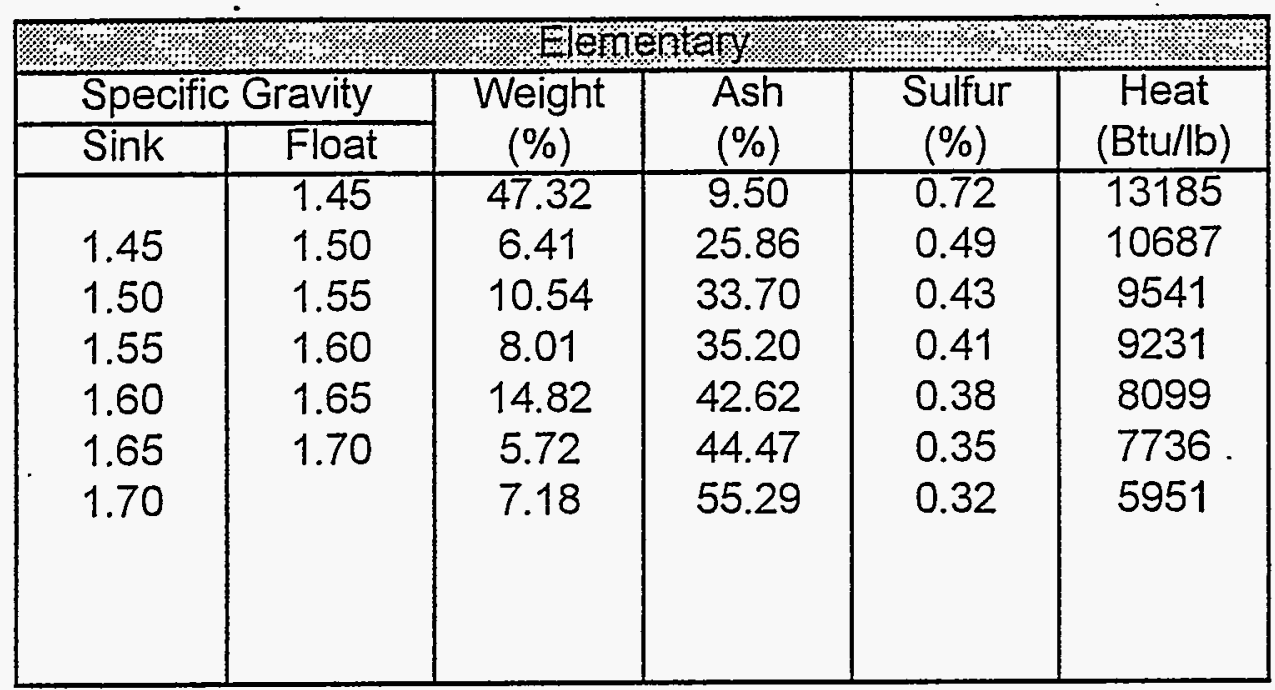

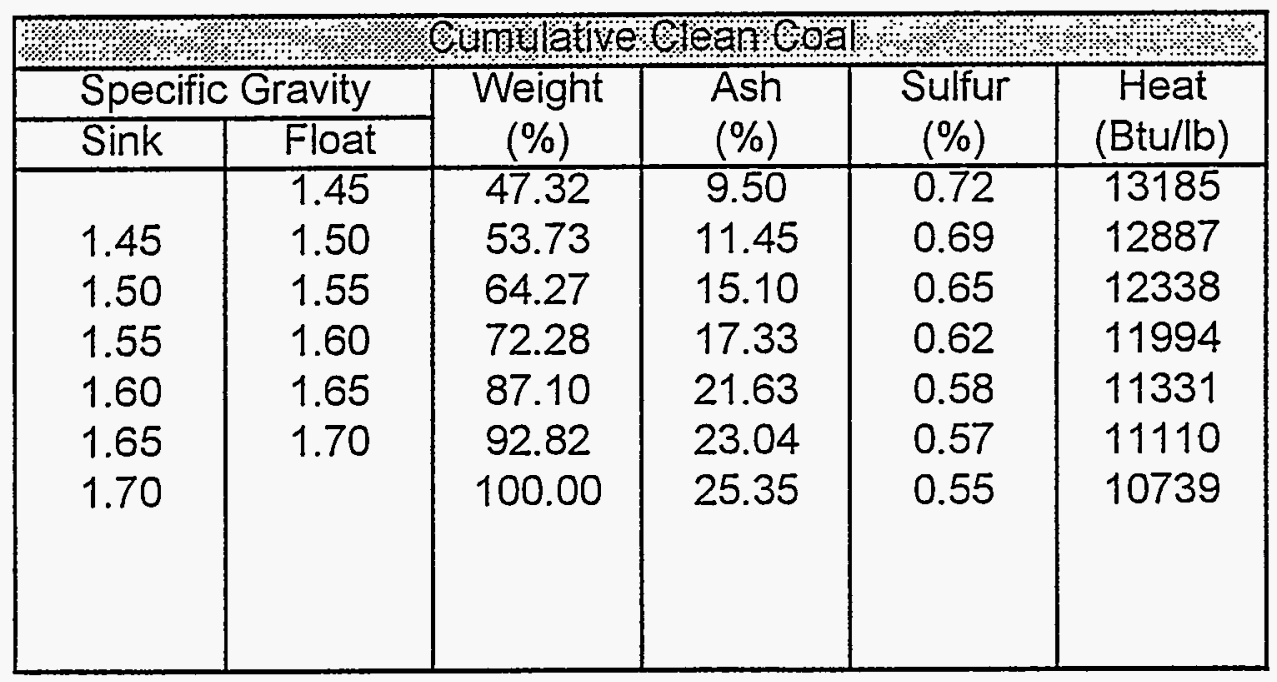

\begin{tabular}{|c|c|c|c|c|c|}
\hline \multicolumn{6}{|c|}{ / } \\
\hline \multicolumn{2}{|c|}{ Specific Gravity } & \multirow{2}{*}{$\begin{array}{l}\text { Weight } \\
(\%)\end{array}$} & \multirow{2}{*}{$\begin{array}{l}\text { Ash } \\
(\%)\end{array}$} & \multirow{2}{*}{$\begin{array}{c}\text { Sulfur } \\
(\%)\end{array}$} & \multirow{2}{*}{$\begin{array}{c}\text { Heat } \\
\text { (Btu/lb) }\end{array}$} \\
\hline Sink & Float & & & & \\
\hline & 1.45 & 100.00 & 25.35 & 0.55 & 10739 \\
\hline 1.45 & 1.50 & 52.68 & 39.60 & 0.40 & 8542 \\
\hline 1.50 & 1.55 & 46.27 & 41.50 & 0.38 & 8245 \\
\hline 1.55 & 1.60 & 35.73 & 43.80 & 0.37 & 7863 \\
\hline 1.60 & 1.65 & 27.72 & 46.28 & 0.36 & 7468 \\
\hline 1.65 & 1.70 & 12.90 & 50.49 & 0.33 & 6742 \\
\hline 1.70 & & 7.18 & 55.29 & 0.32 & 5951 \\
\hline & & & & & \\
\hline & & & & & \\
\hline
\end{tabular}




\begin{tabular}{|c|c|c|c|c|c|}
\hline \multirow{2}{*}{\multicolumn{2}{|c|}{$\frac{\text { ४) }}{\text { Specific Gravity }}$}} & \multicolumn{2}{|c|}{ Meneatay } & \multirow{3}{*}{$\begin{array}{l}\text { Sulfur } \\
(\%) \\
\end{array}$} & \multirow{3}{*}{$\begin{array}{c}\text { Heat } \\
\text { (Btu/lb) }\end{array}$} \\
\hline & & \multirow{2}{*}{$\begin{array}{c}\text { Weight } \\
(\%)\end{array}$} & \multirow{2}{*}{$\begin{array}{l}\text { Ash } \\
(\%)\end{array}$} & & \\
\hline Sink & Float & & & & \\
\hline & 1.45 & 61.81 & 6.34 & 0.71 & 13511 \\
\hline 1.45 & 1.50 & 2.28 & 14.97 & 0.55 & 11623 \\
\hline 1.50 & 1.55 & 6.02 & 19.62 & 0.50 & 10979 \\
\hline 1.55 & 1.60 & 3.74 & 23.79 & 0.46 & 10393 \\
\hline 1.60 & 1.65 & 2.87 & 28.21 & 0.39 & 9751 \\
\hline 1.65 & 1.70 & 3.04 & 33.77 & 0.39 & 8968 \\
\hline 1.70 & & 20.24 & 60.54 & 0.34 & 5085 \\
\hline & & & & & \\
\hline & & & & & \\
\hline
\end{tabular}

\begin{tabular}{|c|c|c|c|c|c|}
\hline \multicolumn{2}{|c|}{$4 \% \%$} & Equilatil & eanke & $4+\frac{1}{4}$ & $\sqrt{4} \times \mathbf{4}$ \\
\hline \multicolumn{2}{|c|}{ Specific Gravity } & \multirow{2}{*}{$\begin{array}{c}\text { Weight } \\
(\%)\end{array}$} & \multirow{2}{*}{$\begin{array}{l}\text { Ash } \\
(\%)\end{array}$} & \multirow{2}{*}{$\begin{array}{l}\text { Sulfur } \\
(\%)\end{array}$} & \multirow{2}{*}{$\begin{array}{c}\text { Heat } \\
\text { (Btu/lb) }\end{array}$} \\
\hline Sink & Float & & & & \\
\hline & 1.45 & 61.81 & 6.34 & 0.71 & 13511 \\
\hline 1.45 & 1.50 & 64.09 & 6.65 & 0.70 & 13444 \\
\hline 1.50 & 1.55 & 70.11 & 7.76 & 0.69 & 13232 \\
\hline 1.55 & 1.60 & 73.85 & 8.57 & 0.68 & 13088 \\
\hline 1.60 & 1.65 & 76.72 & 9.31 & 0.66 & 12964 \\
\hline 1.65 & 1.70 & 79.76 & 10.24 & 0.65 & 12811 \\
\hline 1.70 & & 100.00 & 20.42 & 0.59 & 11247 \\
\hline & & & & & \\
\hline & & & & & \\
\hline
\end{tabular}

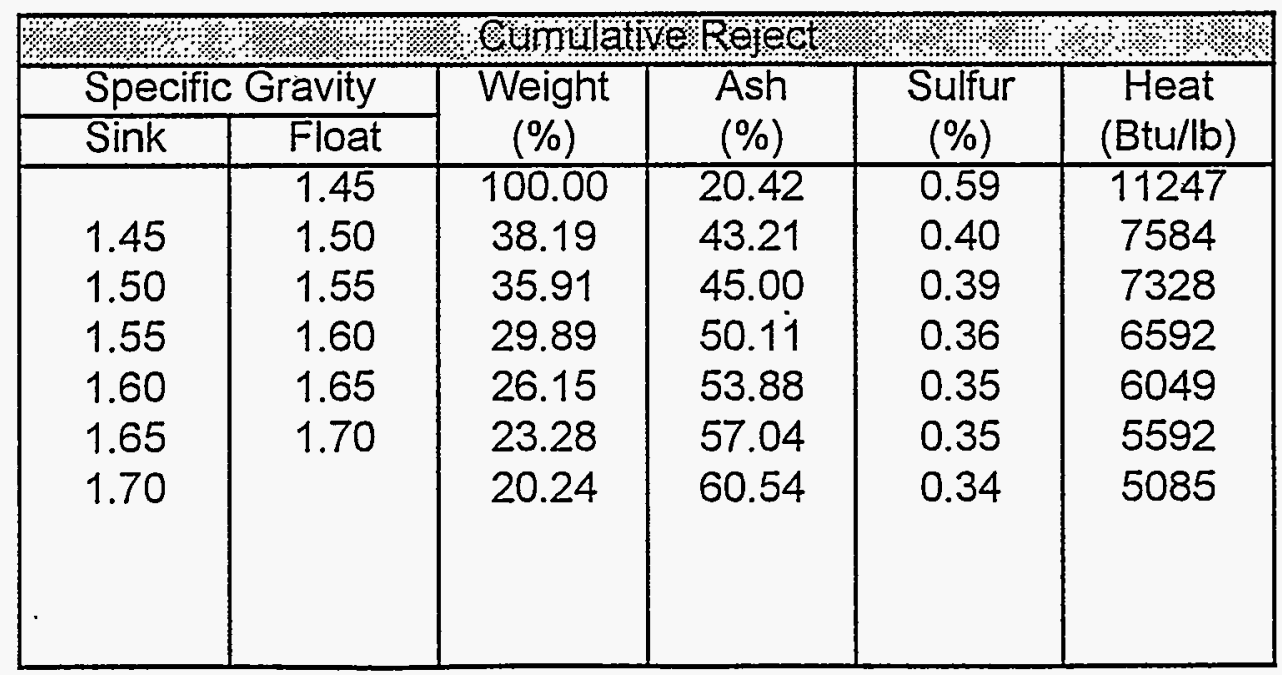


Pittsburgh No. 8 Seam

\begin{tabular}{|c|c|c|c|c|}
\hline \multicolumn{2}{|c|}{ Size Class } & \multirow{2}{*}{$\begin{array}{c}\text { Elementary } \\
(\%)\end{array}$} & \multirow{2}{*}{$\begin{array}{l}\text { Retained } \\
(\%)\end{array}$} & \multirow{2}{*}{$\begin{array}{c}\text { Passing } \\
(\%)\end{array}$} \\
\hline Passing & Retained & & & \\
\hline & 1 Inch & 26.39 & 26.39 & 100.00 \\
\hline 1 Inch & $1 / 2$ Inch & 21.88 & 48.27 & 73.61 \\
\hline 1/2 Inch & 3/8 Inch & 8.44 & 56.71 & 51.73 \\
\hline 3/8 Inch & 1/4 Inch & 10.58 & 67.29 & 43.29 \\
\hline 1/4 Inch & 48 Mesh & 25.93 & 93.22 & 32.71 \\
\hline 48 Mesh & 100 Mesh & 1.97 & 95.19 & 6.78 \\
\hline 100 Mesh & & 4.81 & 100.00 & 4.81 \\
\hline & & & & \\
\hline & & & & \\
\hline
\end{tabular}


Pittsburgh No. 8 Seam

\begin{tabular}{|c|c|c|c|c|}
\hline \multicolumn{2}{|c|}{ Size Class } & \multirow{2}{*}{$\begin{array}{c}\text { Elementary } \\
(\%)\end{array}$} & \multirow{2}{*}{$\begin{array}{l}\text { Retained } \\
(\%)\end{array}$} & \multirow{2}{*}{$\begin{array}{l}\text { Passing } \\
(\%)\end{array}$} \\
\hline Passing & Retained & & & \\
\hline & 1 lnch & 26.39 & 26.39 & 100.00 \\
\hline 1 Inch & $1 / 2$ Inch & 21.88 & 48.27 & 73.61 \\
\hline $1 / 2$ Inch & $3 / 8$ lnch & 8.44 & 56.71 & 51.73 \\
\hline $3 / 8$ Inch & $1 / 4$ Inch & 10.58 & 67.29 & 43.29 \\
\hline $1 / 4$ Inch & 48 Mesh & 25.93 & 93.22 & 32.71 \\
\hline 48 Mesh & 100 Mesh & 1.97 & 95.19 & 6.78 \\
\hline 100 Mesh & & 4.81 & 100.00 & 4.81 \\
\hline & & & & \\
\hline & & & & \\
\hline
\end{tabular}


Pittsburgh No. 8 Seam

Plus 1 Inch - 26.39\% Wt.

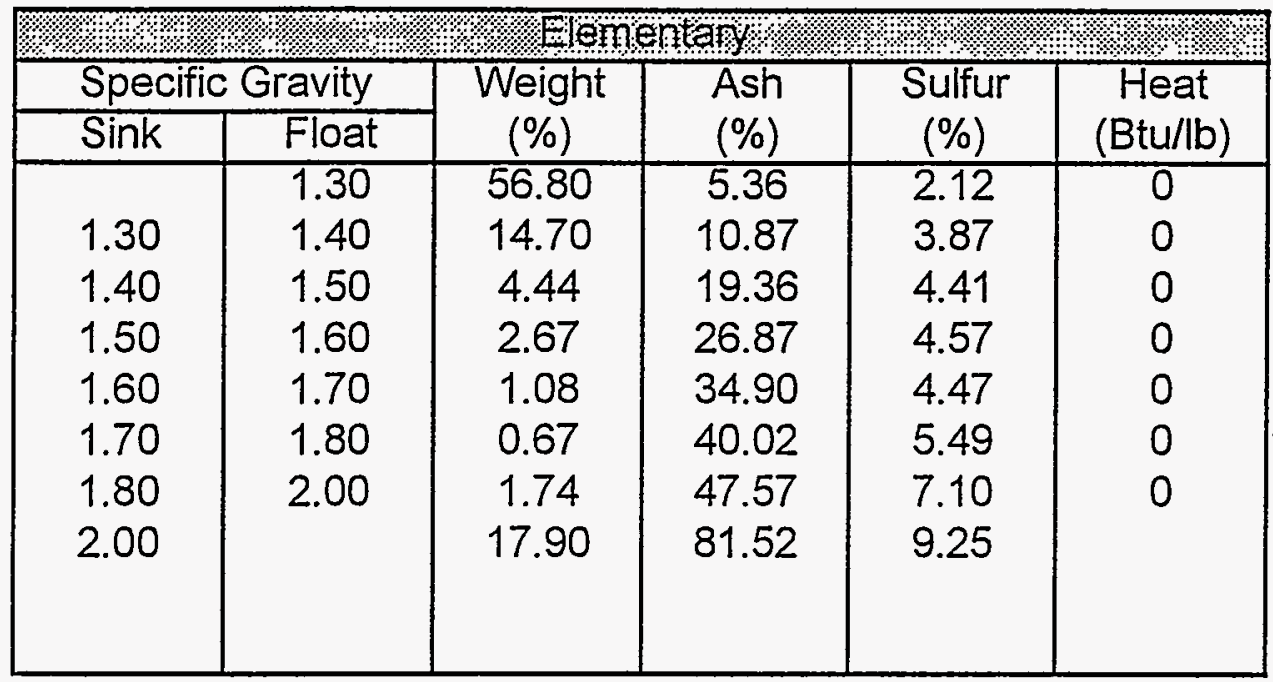

\begin{tabular}{|c|c|c|c|c|c|}
\hline \multicolumn{2}{|c|}{ "অ:/ } & \multicolumn{4}{|c|}{ 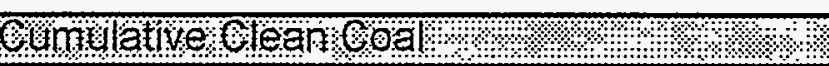 } \\
\hline \multicolumn{2}{|c|}{ Specific Gravity } & Weight & Ash & Sulfur & Heat \\
\hline Sink & Float & $(\%)$ & (\%) & $(\%)$ & (Btu/lb) \\
\hline & 1.30 & 56.80 & 5.36 & 2.12 & 0 \\
\hline 1.30 & 1.40 & 71.50 & 6.49 & 2.48 & 0 \\
\hline 1.40 & 1.50 & 75.94 & 7.25 & 2.59 & 0 \\
\hline 1.50 & 1.60 & 78.61 & 7.91 & 2.66 & 0 \\
\hline 1.60 & 1.70 & 79.69 & 8.28 & 2.68 & 0 \\
\hline 1.70 & 1.80 & 80.36 & 8.54 & 2.71 & 0 \\
\hline 1.80 & 2.00 & 82.10 & 9.37 & 2.80 & 0 \\
\hline 2.00 & & 100.00 & 22.28 & 3.96 & 0 \\
\hline
\end{tabular}

\begin{tabular}{|c|c|c|c|c|c|}
\hline \multirow{2}{*}{\multicolumn{2}{|c|}{ Specific Gravity }} & \multirow{3}{*}{$\begin{array}{l}\text { Weingla } \\
\text { Weight } \\
(\%)\end{array}$} & \multirow{3}{*}{ 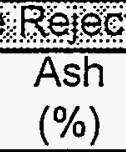 } & 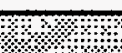 & 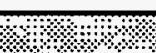 \\
\hline & & & & \multirow{2}{*}{$\begin{array}{c}\text { Sulfur } \\
(\%)\end{array}$} & \multirow{2}{*}{$\begin{array}{l}\text { Heat } \\
(\mathrm{Btu} / \mathrm{lb})\end{array}$} \\
\hline Sink & Floal & & & & \\
\hline & 1.30 & 100.00 & 22.28 & 3.96 & 0 \\
\hline 1.30 & 1.40 & 43.20 & 44.54 & 6.37 & 0 \\
\hline 1.40 & 1.50 & 28.50 & 61.90 & 7.66 & 0 \\
\hline 1.50 & 1.60 & 24.06 & 69.75 & 8.26 & 0 \\
\hline 1.60 & 1.70 & 21.39 & 75.10 & 8.72 & 0 \\
\hline 1.70 & 1.80 & 20.31 & 77.24 & 8.94 & 0 \\
\hline 1.80 & 2.00 & 19.64 & 78.51 & 9.06 & 0 \\
\hline 2.00 & & 17.90 & 81.52 & 9.25 & 0 \\
\hline
\end{tabular}




\begin{tabular}{|c|c|c|c|c|c|}
\hline \multirow{2}{*}{\multicolumn{2}{|c|}{ Specific Gravity }} & \multirow{3}{*}{$\begin{array}{c}\text { ferem } \\
\text { Weight } \\
(\%)\end{array}$} & tany & & \\
\hline & & & \multirow{2}{*}{$\begin{array}{l}\text { Ash } \\
(\%)\end{array}$} & \multirow{2}{*}{$\begin{array}{l}\text { Sulfur } \\
(\%)\end{array}$} & \multirow{2}{*}{$\begin{array}{c}\text { Heat } \\
\text { (Btu/lb) }\end{array}$} \\
\hline Sink & Float & & & & \\
\hline & 1.30 & 67.05 & $\overline{5.12}$ & 2.00 & $\overline{0}$ \\
\hline 1.30 & 1.40 & 9.40 & 9.62 & 3.34 & 0 \\
\hline 1.40 & 1.50 & 7.20 & 15.35 & 4.53 & 0 \\
\hline 1.50 & 1.60 & 2.30 & 23.68 & 5.38 & 0 \\
\hline 1.60 & 1.70 & 1.51 & 32.22 & 5.34 & 0 \\
\hline 1.70 & 1.80 & 0.87 & 38.29 & 5.63 & 0 \\
\hline 1.80 & 2.00 & 1.11 & 46.08 & 5.74 & 0 \\
\hline 2.00 & & 10.56 & 80.83 & 7.12 & 0 \\
\hline
\end{tabular}

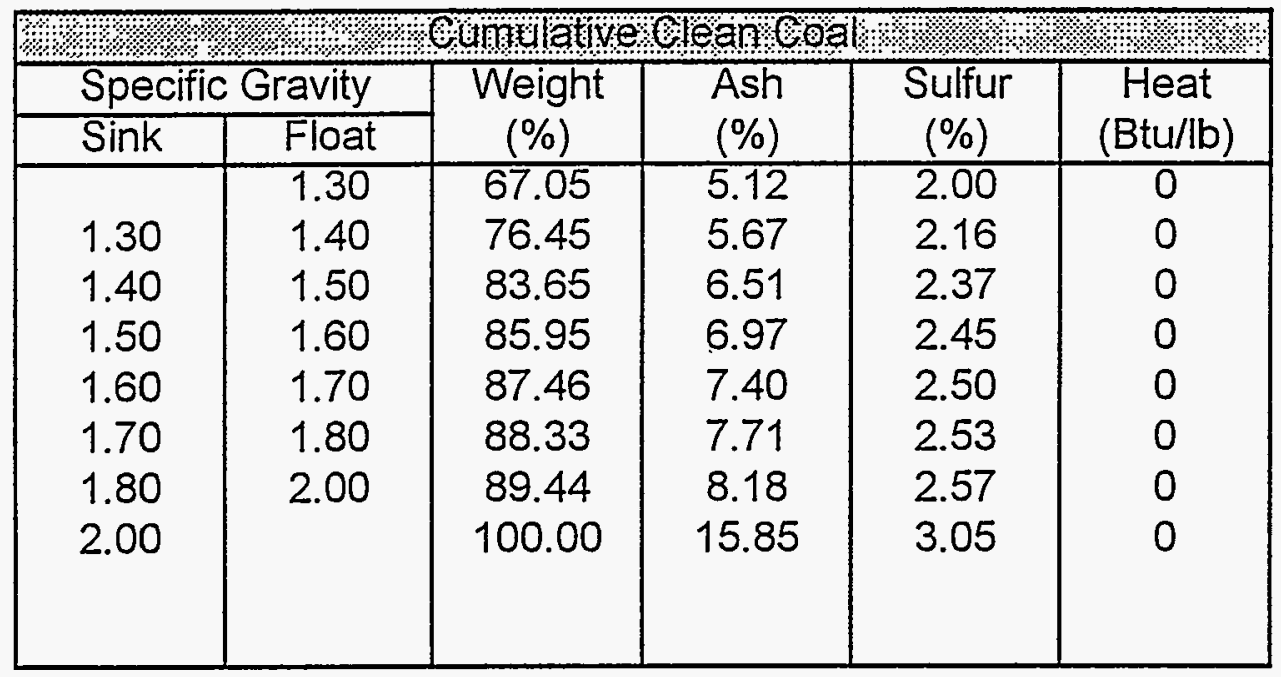

\begin{tabular}{|c|c|c|c|c|c|}
\hline \multicolumn{6}{|c|}{ 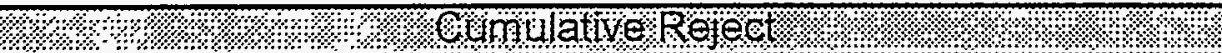 } \\
\hline \multicolumn{2}{|c|}{ Specific Gravity } & Weight & Ash & Sulfur & Heat \\
\hline Sink & Float & $(\%)$ & (\%) & (\%) & (Btu/lb) \\
\hline & 1.30 & 100.00 & 15.85 & 3.05 & $\overline{0}$ \\
\hline 1.30 & 1.40 & 32.95 & 37.70 & 5.19 & 0 \\
\hline 1.40 & 1.50 & 23.55 & 48.90 & 5.92 & 0 \\
\hline 1.50 & 1.60 & 16.35 & 63.68 & 6.54 & 0 \\
\hline 1.60 & 1.70 & 14.05 & 70.23 & 6.73 & 0 \\
\hline 1.70 & 1.80 & 12.54 & 74.80 & 6.89 & 0 \\
\hline 1.80 & 2.00 & 11.67 & 77.52 & 6.99 & 0 \\
\hline 2.00 & & 10.56 & 80.83 & 7.12 & 0 \\
\hline
\end{tabular}




\begin{tabular}{|c|c|c|c|c|c|}
\hline \multicolumn{2}{|c|}{ 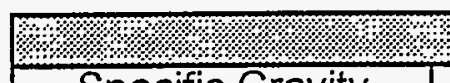 } & \multicolumn{4}{|c|}{ Elementar } \\
\hline \multicolumn{2}{|c|}{ Specific Gravity } & \multirow{2}{*}{$\begin{array}{c}\text { Weight } \\
(\%)\end{array}$} & \multirow{2}{*}{$\begin{array}{l}\text { Ash } \\
(\%)\end{array}$} & \multirow{2}{*}{$\begin{array}{c}\text { Sulfur } \\
(\%)\end{array}$} & \multirow{2}{*}{$\begin{array}{c}\text { Heat } \\
\text { (Btu/lb) }\end{array}$} \\
\hline Sink & Float & & & & \\
\hline & 1.30 & 54.93 & 4.66 & 1.78 & $\overline{0}$ \\
\hline 1.30 & 1.40 & 30.21 & 8.95 & 3.00 & 0 \\
\hline 1.40 & 1.50 & 1.56 & 18.56 & 5.16 & 0 \\
\hline 1.50 & 1.60 & 1.69 & 24.20 & 5.73 & 0 \\
\hline 1.60 & 1.70 & 1.38 & 29.46 & 6.06 & 0 \\
\hline 1.70 & 1.80 & 0.68 & 39.61 & 6.37 & 0 \\
\hline 1.80 & 2.00 & 1.12 & 43.55 & 6.10 & 0 \\
\hline 2.00 & & 8.43 & 80.40 & 8.30 & 0 \\
\hline
\end{tabular}

\begin{tabular}{|c|c|c|c|c|c|}
\hline \multicolumn{2}{|c|}{ \%?/ } & \multicolumn{2}{|c|}{ Und lativerean } & \multicolumn{2}{|c|}{$\because \% \%$} \\
\hline \multicolumn{2}{|c|}{ Specific Gravity } & Weight & Ash & Sulfur & Heat \\
\hline Sink & Float & (\%) & $(\%)$ & $(\%)$ & (Btu/lb) \\
\hline & 1.30 & 54.93 & 4.66 & 1.78 & 0 \\
\hline 1.30 & 1.40 & 85.14 & 6.18 & 2.21 & 0 \\
\hline 1.40 & 1.50 & 86.70 & 6.40 & 2.27 & 0 \\
\hline 1.50 & 1.60 & 88.39 & 6.75 & 2.33 & 0 \\
\hline 1.60 & 1.70 & 89.77 & 7.09 & 2.39 & 0 \\
\hline 1.70 & 1.80 & 90.45 & 7.34 & 2.42 & 0 \\
\hline 1.80 & 2.00 & 91.57 & 7.78 & 2.46 & 0 \\
\hline 2.00 & & 100.00 & 13.90 & 2.96 & 0 \\
\hline
\end{tabular}

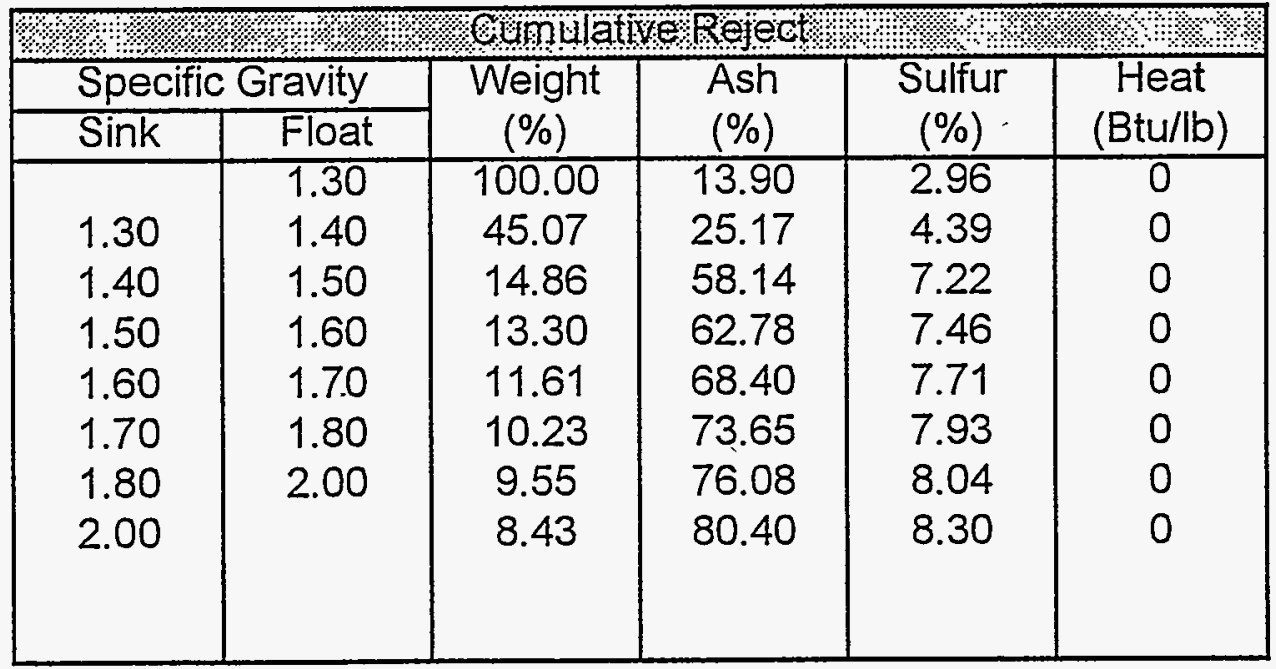




\begin{tabular}{|c|c|c|c|c|c|}
\hline \multicolumn{2}{|c|}{ Pl: } & \multicolumn{2}{|c|}{ Eemertany } & \multirow{2}{*}{$\begin{array}{l}\text { Sulfur } \\
\text { Sul }\end{array}$} & \multirow{3}{*}{$\begin{array}{c}\text { Heat } \\
\text { (Btu/lb) }\end{array}$} \\
\hline Spec & ravity & Weight & Ash & & \\
\hline Sink & Float & $(\%)$ & $(\%)$ & $(\%)$ & \\
\hline & 1.30 & 51.31 & 4.47 & 1.74 & $\overline{0}$ \\
\hline 1.30 & 1.40 & 32.11 & 7.86 & 2.69 & 0 \\
\hline 1.40 & 1.50 & 4.05 & 16.07 & 4.96 & 0 \\
\hline 1.50 & 1.60 & 2.06 & 21.64 & 5.73 & 0 \\
\hline 1.60 & 1.70 & 0.97 & 32.21 & 6.72 & 0 \\
\hline 1.70 & 1.80 & 0.58 & 39.13 & 6.34 & 0 \\
\hline 1.80 & 2.00 & 1.04 & 44.87 & 6.64 & 0 \\
\hline 2.00 & & 7.88 & 80.18 & 8.45 & 0 \\
\hline
\end{tabular}

\begin{tabular}{|c|c|c|c|c|c|}
\hline & \multicolumn{4}{|c|}{ 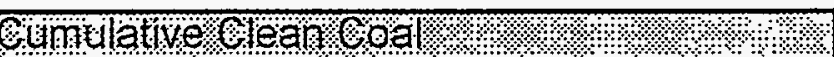 } \\
\hline \multicolumn{2}{|c|}{ Specific Gravity } & Weight & Ash & Sulfur & Heat \\
\hline$\overline{S i n k}$ & Float & $(\%)$ & $(\%)$ & $(\%)$ & (Btu/lb) \\
\hline & 1.30 & 51.31 & 4.47 & 1.74 & -0 \\
\hline 1.30 & 1.40 & 83.42 & 5.77 & 2.11 & 0 \\
\hline 1.40 & 1.50 & 87.47 & 6.25 & 2.24 & 0 \\
\hline 1.50 & 1.60 & 89.53 & 6.61 & 2.32 & 0 \\
\hline 1.60 & 1.70 & 90.50 & 6.88 & 2.37 & 0 \\
\hline 1.70 & 1.80 & 91.08 & 7.09 & 2.39 & 0 \\
\hline 1.80 & 2.00 & 92.12 & 7.51 & 2.44 & 0 \\
\hline 2.00 & & 100.00 & 13.24 & 2.91 & 0 \\
\hline
\end{tabular}

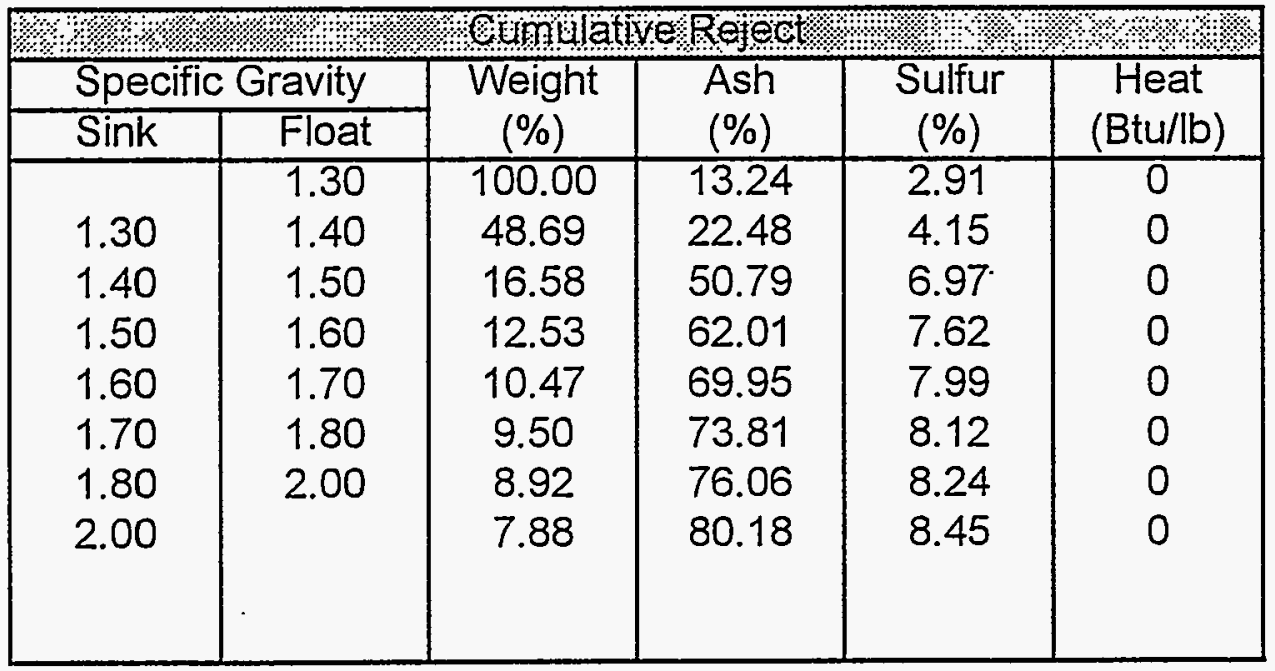




\begin{tabular}{|c|c|c|c|c|c|}
\hline \multicolumn{6}{|c|}{ Eleneatary } \\
\hline \multicolumn{2}{|c|}{ Specific Gravity } & \multirow{2}{*}{$\begin{array}{c}\text { Weight } \\
(\%)\end{array}$} & \multirow{2}{*}{$\begin{array}{l}\text { Ash } \\
(\%)\end{array}$} & \multirow{2}{*}{$\begin{array}{c}\text { Sulfur } \\
(\%)\end{array}$} & \multirow{2}{*}{$\begin{array}{l}\text { Heat } \\
\text { (Btu/lb) }\end{array}$} \\
\hline Sink & Float & & & & \\
\hline & 1.30 & 72.95 & 3.83 & 1.76 & $\overline{0}$ \\
\hline 1.30 & 1.40 & 12.97 & 9.22 & 3.04 & 0 \\
\hline 1.40 & 1.50 & 3.53 & 15.94 & 5.09 & 0 \\
\hline 1.50 & 1.60 & 1.37 & 23.97 & 6.30 & 0 \\
\hline 1.60 & 1.70 & 0.91 & 30.24 & 6.89 & 0 \\
\hline 1.70 & 1.80 & 0.50 & 35.14 & 6.67 & 0 \\
\hline 1.80 & 2.00 & 0.94 & 41.70 & 7.06 & 0 \\
\hline 2.00 & & 6.83 & 79.39 & 9.38 & 0 \\
\hline
\end{tabular}

\begin{tabular}{|c|c|c|c|c|c|}
\hline \multicolumn{6}{|c|}{ 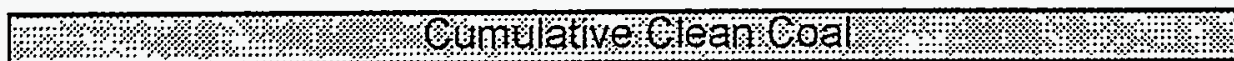 } \\
\hline \multicolumn{2}{|c|}{ Specific Gravity } & \multirow{2}{*}{$\begin{array}{c}\text { Weight } \\
(\%)\end{array}$} & \multirow{2}{*}{$\begin{array}{l}\text { Ash } \\
(\%)\end{array}$} & \multirow{2}{*}{$\begin{array}{c}\text { Sulfur } \\
(\%)\end{array}$} & \multirow{2}{*}{$\begin{array}{c}\text { Heat } \\
\text { (Btu/lb) }\end{array}$} \\
\hline Sink & Float & & & & \\
\hline & 1.30 & 72.95 & 3.83 & 1.76 & 0 \\
\hline 1.30 & 1.40 & 85.92 & 4.64 & 1.95 & 0 \\
\hline 1.40 & 1.50 & 89.45 & 5.09 & 2.08 & 0 \\
\hline 1.50 & 1.60 & 90.82 & 5.37 & 2.14 & 0 \\
\hline 1.60 & 1.70 & 91.73 & 5.62 & 2.19 & 0 \\
\hline 1.70 & 1.80 & 92.23 & 5.78 & 2.21 & 0 \\
\hline 1.80 & 2.00 & 93.17 & 6.14 & 2.26 & 0 \\
\hline 2.00 & & 100.00 & 11.15 & 2.75 & 0 \\
\hline & & & & & \\
\hline
\end{tabular}

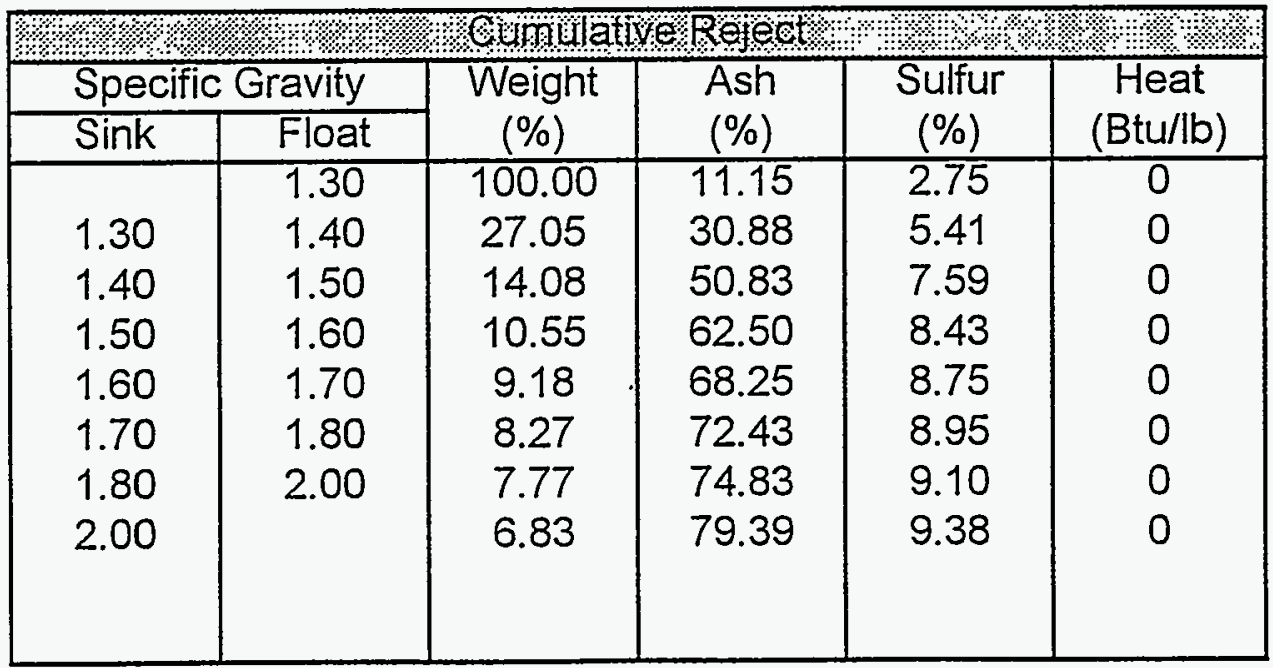


Pittsburgh No. 8 Seam

$48 \times 100$ Mesh $-1.97 \%$ Wt.

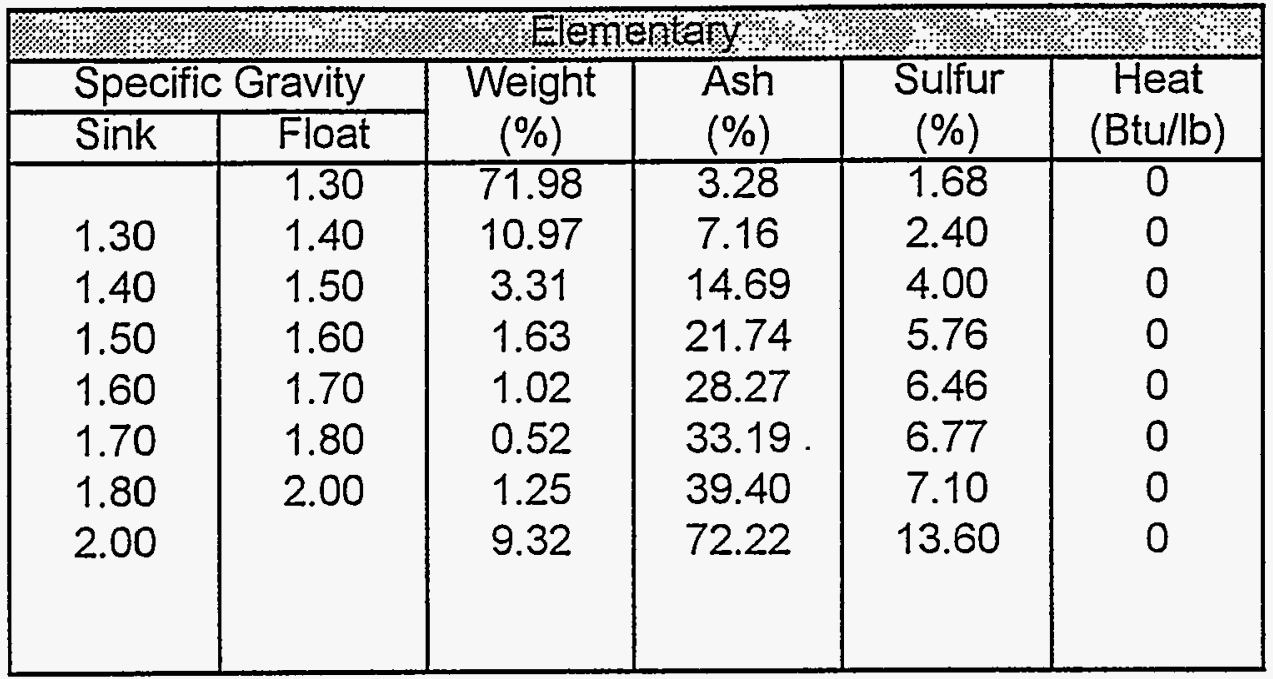

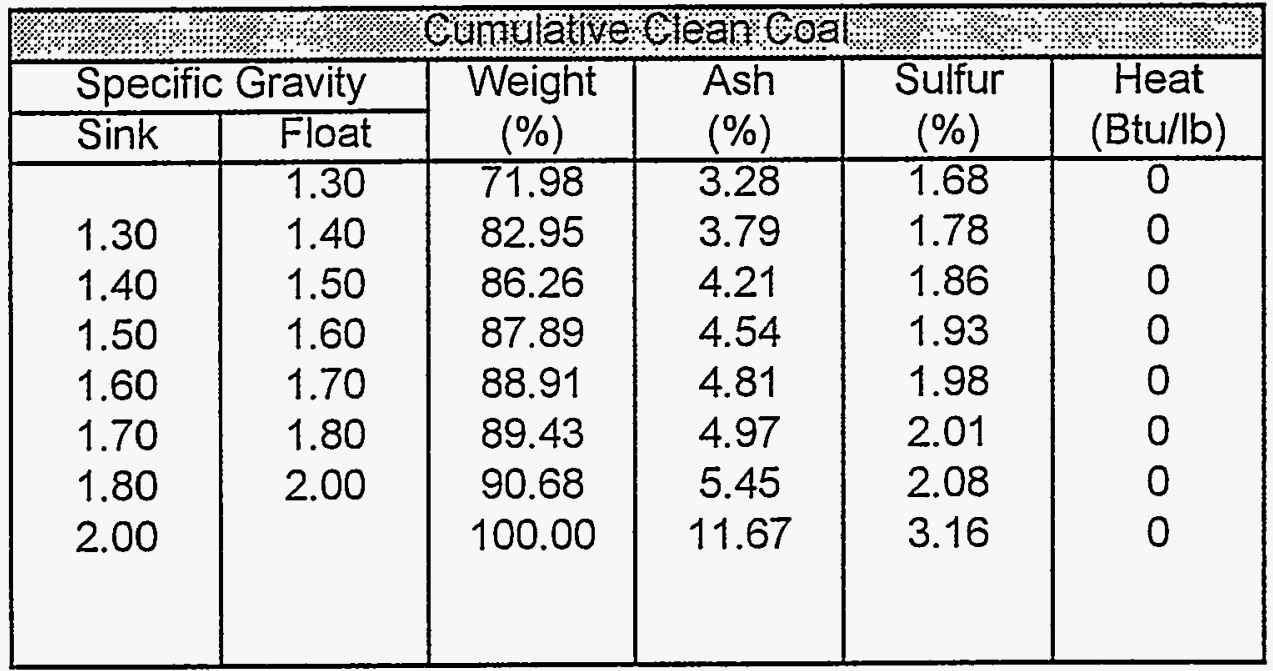

\begin{tabular}{|c|c|c|c|c|c|}
\hline \multirow{2}{*}{\multicolumn{2}{|c|}{ Specific Gravity }} & CuIn⿴囗十⺝ & Refect & 8 & W \\
\hline & & \multirow{2}{*}{$\begin{array}{c}\text { Weight } \\
(\%)\end{array}$} & \multirow{2}{*}{$\begin{array}{l}\text { Ash } \\
(\%)\end{array}$} & \multirow{2}{*}{$\begin{array}{c}\text { Sulfur } \\
(\%)\end{array}$} & \multirow{2}{*}{$\begin{array}{c}\text { Heat } \\
\text { (Btu/lb) }\end{array}$} \\
\hline Sink & Float & & & & \\
\hline & 1.30 & 100.00 & 11.67 & 3.16 & 0 \\
\hline 1.30 & 1.40 & 28.02 & 33.23 & 6.95 & 0 \\
\hline 1.40 & 1.50 & 17.05 & 50.00 & 9.87 & 0 \\
\hline 1.50 & 1.60 & 13.74 & 58.51 & 11.29 & 0 \\
\hline 1.60 & 1.70 & 12.11 & 63.45 & 12.03 & 0 \\
\hline 1.70 & 1.80 & 11.09 & 66.69 & 12.55 & 0 \\
\hline 1.80 & 2.00 & 10.57 & 68.34 & 12.83 & 0 \\
\hline 2.00 & & 9.32 & 72.22 & 13.60 & 0 \\
\hline
\end{tabular}

